\title{
13. \\ DRUGI SVJETSKI RAT U ČLANCIMA I GOVORIMA JOSIPA BROZA TITA (1940.-1948.)
}

\section{Snježana Koren}

UDK: 32-05Tito"1940/48“(045)

Izvorni znanstveni članak

Sažetak: Pripovijest o „Narodnooslobodilačkoj borbi” bila je važna uporišna točka u legitimacijskom diskursu jugoslavenskih komunističkih vlasti, a u velikoj se mjeri temeljila upravo na radovima Josipa Broza Tita. Svoje ključne radove posvećene NOB-u Tito je napisao u razdoblju od 1941. do 1948. godine, dok se ratu kasnije vraćao uglavnom kroz svoja sjećanja, intervjue i prigodne govore. U radu se stoga analiziraju i kontekstualiziraju njegovi članci, politički referati i prigodni govori nastali u navedenom razdoblju, kao i ključni obrasci i predodžbe o ratu koji su postavljeni u Titovim radovima. Posebna pozornost posvećena je referatu na Petom kongresu KPJ 1948. godine, pri čemu se nastoje utvrditi razlike u odnosu na ranije tekstove, odnosno nova značenja pripisana NOB-u u promijenjenom političkom kontekstu sukoba sa SSSR-om. Posljednje poglavlje donosi okvirni osvrt na recepciju Titova djela nakon 1948. godine.

Ključne riječi: Josip Broz Tito, Drugi svjetski rat, NOB, članci i govori nastali u ratu, referat na Petom kongresu KPJ, pripovijest, ustanak, sedam ofenziva, revolucija, sjećanje na rat

odine 1955. Jugoslavenski je nacionalni komitet za historijske znanosti objavio povofom sudjelovanja jugoslavenskih historičara na Desetom međunarodnom kongresu povijesnih znanosti u Rimu zbornik Deset godina jugoslavenske historiografije 1945$1955 .{ }^{1} \mathrm{U}$ zborniku je nizom članaka na francuskom i engleskom jeziku predstavljen razvoj jugoslavenske historiografije. I dok su u prikazima historiografije za starija povijesna razdoblja redom navedeni radovi profesionalnih povjesničara, za historiografiju razdoblja nakon 1918. godine, a osobito za razdoblje Drugog svjetskog rata, slika je bitno drugačija: primat nad povjesničarima dobili su radovi Josipa Broza Tita i drugih visokih partijskih dužnosnika i teoretičara iz samog vrha KPJ/SKJ. Radova o razdoblju Drugoga svjetskog rata povjesničara zaposlenih na katedrama za povijest jugoslavenskih filozofskih fakulteta u tom zborniku nije bilo: oni su ovu temu uglavnom izbjegavali jer je zbog značaja koji su joj

Dix années d'historiographie yougoslave 1945-1955, (ur. Jorjo Tadić), Beograd 1955. 
pridavale jugoslavenske komunističke vlasti bila pod pojačanom paskom Partije. U drugoj polovici 1950-ih Ideološka komisija pri CK SKJ žalila se upravo na teoriju distance koja je povjesničarima služila kao svojevrsni štit i argument protiv bavljenja najnovijom poviješću. ${ }^{2}$

Ovu su prazninu donekle nadopunjavala popularno pisana djela koja su se uvelike oslanjala upravo na Titove radove. U 1940-ima i 1950-ima nastalo je nekoliko takvih knjiga koje su se tiskale u izdašnim tiražama i na različitim jezicima. Radilo se, primjerice, o knjigama Pregled Narodnooslobodilačke borbe generala Arse Jovanovića (1946.), ${ }^{3}$ Pregled historije narodnooslobodilačke borbe Jugoslavije profesora Više pedagoške škole u Zagrebu Tome Čubelića i majora Milovana Milostića (1952. ${ }^{4}$ i Narodnooslobodilački rat. Narodna revolucija u Jugoslaviji 1941-1945. (1957.) Jovana Marjanovića, tada direktora Državnog arhiva FNRJ i od 1961. profesora predmeta Istorija narodne/socijalističke revolucije na Filozofskom fakultetu u Beogradu. ${ }^{5}$ Prvo djelo iz pera nekog povjesničara koji je radio na fakultetu bila je knjiga Pregled razvoja NOB u Sloveniji (1956.) Metoda Mikuža, profesora na Filozofskom fakultetu u Ljubljani. ${ }^{6}$ Tek s oživljavanjem rada specijaliziranih institucija poput Instituta za društvene znanosti u Beogradu ili republičkih instituta za historiju radničkog pokreta koji su osnovani na prijelazu iz 1950-ih u 1960-e godine teme iz novije povijesti počele su se intenzivnije istraživati.

Stoga nije ni čudo da su radovi Josipa Broza Tita i drugih vodećih komunista dugo vremena imali primat u oblikovanju predodžbi i sjećanja o Drugom svjetskom ratu. No, razlog tomu nije bio samo nedostatak drugih radova o ratu. Pripovijest o „Narodnooslobodilačkoj borbi” bila je važna uporišna točka u legitimacijskom diskursu jugoslavenskih komunističkih vlasti. NOB se još tijekom rata počeo prikazivati kao utemeljujući dogadaj druge Jugoslavije, a poslije rata postao je jednim od ključnih čimbenika u pokušajima oblikovanja zajedničkog jugoslavenskog identiteta. Predodžba o zajedničkoj borbi svih jugoslavenskih naroda protiv okupatora i njihovih pomagača bila je ugrađena u same temelje dominante ideologije bratstva i jedinstva. Snažno uvjerenje o tome da je NOB historijska prekretnica, događaj od izuzetnog značaja ne samo u povijesti jugoslavenskih naroda nego i u svjetskim razmjerima, može se zapaziti u tekstovima Tita i drugih ljudi iz najužeg partijskog vrha još tijekom rata. Isticanje veličine i autentičnosti narodnooslobodilačke borbe naroda Jugoslavije imalo je, kao što je svojedobno napisao Branko Petranović, snažan emancipacijski karakter čak i u razdoblju kada je odnos prema SSSR-u bio najapologetskiji.?

\footnotetext{
Više o tome vidi u: Snježana KOREN, Politika povijesti u Jugoslaviji (1945-1960): Komunistička partija Jugoslavije, nastava povijesti, historiografija, Zagreb 2012.; Magdalena NAJBAR-AGIČIĆ, U skladu s marksizmom ili ćinjenicama? Hrvatska historiografija 1945-1960., Zagreb 2013.

3 Arso JOVANOVIĆ, Pregled narodnooslobodilačke borbe, Beograd 1946. Ova je knjiga doživjela tri izdanja između 1946. i 1948., no prestala se objavljivati nakon Jovanovićeva opredjeljenja za Informbiro i pogibije 1950. godine. Stoga nijedno njegovo djelo, uključujući i ratne radove o Šestoj i Sedmoj ofenzivi, nije uvršteno u spomenutu knjigu Deset godina jugoslavenske historiografije iako su se istovremeno navodili radovi Koste Nađa, Petra Drapšina itd.

4 Tomo ČUBELIĆ - Milovan MILOSTIĆ, Pregled historije Narodnooslobodilačke borbe Jugoslavije, Zagreb 1952. Ova je knjiga u izdanju Matice hrvatske doživjela je čak 11 izdanja (od 1952. do 1963. godine) i bila je prevedena na mađarski, talijanski, albanski i makedonski jezik. Od prvog izdanja iz 1952. do posljednjeg iz 1963. gotovo je svake godine doživljavala promjene i izmjene, ukazujući tako na stalni rad na sjećanju o NOB-u koji se odvijao u poslijeratnim godinama.

5 Jovan MARJANOVIĆ, Narodnooslobodilački rat, naroda revolucija u Jugoslaviji 1941-1945: kratak pregled, Beograd 1957. Ova je knjiga prvobitno bila objavljena za inozemne čitatelje (na ruskom).

6 Metod MIKUŽ, Pregled razvoja NOB u Sloveniji, Beograd 1956.

7 Branko PETRANOVIĆ, Istorija Jugoslavije 1918 - 1988. III. Socijalistička Jugoslavija 1945 - 1948., Beograd 1988., 34.-35.
} 


\section{Kako pisati o ratu koji još traje: $\mathrm{NOB}$ u ratnim tekstovima Josipa Broza Tita}

Josip Broz Tito je o Drugome svjetskom ratu (odnosno, pretežno o NOB-u) pisao mnogo. Najveći broj njegovih tekstova nastao je još tijekom rata: radilo se o člancima, političkim referatima, govorima održanima u posebnim prigodama i sličnim tekstovima. Oni su objavljivani u partijskim glasilima poput Proletera i Borbe, u glasilima Vrhovnog štaba i AVNOJ-a kao što su Bilten Vrhovnog štaba, ${ }^{8}$ Vojno-politički pregled, ${ }^{9}$ Narodno oslobodenje, ${ }^{10}$ Nova Jugoslavija ${ }^{11}$ u glasilima masovnih organizacija, listovima pojedinih brigada, dnevnim novinama te u posebnim brošurama koje su se umnažale i tiskale još tijekom rata. Ti su Titovi tekstovi već na samom kraju rata prikupljeni i objavljeni u knjizi Borba za oslobođenje Jugoslavije. Prvo izdanje tiskano je na ćirilici još u jesen 1944. godine, a potom je početkom 1945. objavljeno drugo, dopunjeno izdanje na latinici u kojemu je bilo ukupno 38 tekstova objavljenih u razdoblju od kolovoza 1941. do studenog 1944 . godine. ${ }^{12} \mathrm{U}$ drugo izdanje uvrštena su i četiri rana Titova rada nastala u razdoblju od kolovoza do listopada 1941. koji su naknadno pronađeni u upravi beogradske policije kao zaplijenjena literatura. ${ }^{13}$ Godine 1947. objavljena je pod gotovo identičnim nazivom još jedna knjiga sabranih Titovih radova koja je obuhvatila i nekoliko članaka iz 1945. godine. ${ }^{14}$ Tijekom postojanja socijalističke Jugoslavije Titovi su tekstovi, uključujući i one nastale tijekom rata, doživjeli mnogobrojna izdanja i tiskani su u raznim publikacijama, sabranim i izabranim djelima. ${ }^{15}$ U kasnija izdanja unašane su i određene izmjene: primjerice, u izvornoj verziji jednog od ključnih ratnih tekstova Nacionalno pitanje u Jugoslaviji u svjetlosti narodno-oslobodilačke borbe Tito je istaknuo vjernost KPJ načelu da svaki narod ima pravo na samoodređenje do odcjepljenja koje su „postavili naši veliki učitelji i vođe Lenjin i Staljin”. ${ }^{16}$ No, kasnije je Staljinovo ime uklonjeno, pa se u jednoj od novijih verzija govorilo o principu koji su „postavili naši veliki učitelji Marks, Engels i Lenjin", iako je istovremeno u faksimilu s Titovim rukopisnim zabilješkama uključenom neposredno uz tiskani tekst ostao izvorni izričaj (!). ${ }^{17}$

8 Ovaj je list nekoliko puta mijenjao ime: Bilten Glavnog štaba narodnooslobodilačkih partizanskih odreda Jugoslavije (br. 1-6, kolovoz - rujan 1941.); Bilten Vrhovnog štaba narodnooslobodilačkih partizanskih odreda Jugoslavije (br. 7-11, listopad 1941.); Bilten Vrhovnog štaba narodnooslobodilačke partizanske i dobrovoljačke vojske Jugoslavije (br. 12-19, prosinac 1941. - kolovoz 1942.); Bilten Vrhovnog štaba narodnooslobodilačke vojske i partizanskih odreda Jugoslavije (br. 20-47, rujan 1942. - prosinac 1944.). Prvi brojevi bili su tiskani u ilegalnoj tiskari u Beogradu (prvi broj Tito je i uredio), a od br. 7 Bilten je priređivan i tiskan na teritoriju gdje je boravio i Vrhovni štab (npr. u Užicu, u Foči, u selima u blizini Bosanskog Petrovca, Ključa i Drvara, na Visu, te posljednji dvobroj u Beogradu). Svi brojevi Biltena poslije rata su objavljeni u: Zbornik dokumenata i podataka o narodnooslobodilackkom ratu jugoslovenskih naroda. Tom II: Bilten Vrhovnog štaba Narodnooslobodilačke vojske Jugoslavije 1941-194, Beograd 1949. (dalje: Bilten VŠ).

Dvotjedni časopis koji je objavljivao Vrhovni štab u ljeto i jesen 1942. godine.

10 Glasilo AVNOJ-a, list je izašao triput u vrijeme i nakon prvog zasjedanja. Uređivao ga je Veselin Masleša.

11 Dvotjedni časopis koji je pod uredništvom Milovana Đilasa izlazio tijekom 1944. godine.

12 Josip BROZ TITO, Borba za oslobođenje Jugoslavije: članci i govori iz narodno-oslobodilačke borbe 1941-1944., Beograd 1944.; ISTI, Borba za oslobođenje Jugoslavije: ćlanci i govori iz narodno-oslobodilačke borbe 1941-1944, drugo, dopunjeno izdanje, (redaktori Radovan Zogović i Milovan Đilas), Beograd 1945.

13 J. BROZ TITO, Borba za oslobodenje Jugoslavije, 1945. ${ }^{2}, 245$.

14 ISTI, Borba za oslobodenje Jugoslavije: 1941-1945, sv. 1, Zagreb 1947.

15 Vidi npr.: Josip BROZ TITO, Govori i članci, Zagreb 1959.-1972.; ISTI, Vojna djela, Beograd 1961., 2. dopunjeno izd. 1978.; ISTI, Sabrana djela, (ur. Pero Damjanović), Beograd 1977.-1980.; ISTI, Izbor iz djela, (ur. Muhamed Filipović), Sarajevo 1979.-1982. te brojna druga izdanja.

16 J. BROZ TITO, Borba za oslobodenje Jugoslavije, 19452, 129. „Nacionalno pitanje u Jugoslaviji u svjetlosti narodnooslobodilačke borbe".

17 Vidi npr.: Josip BROZ TITO, Izbor iz djela. Knj. 3: Nacionalno pitanje i revolucija, (ur. Muhamed Filipović), Sarajevo 1979., 72. 


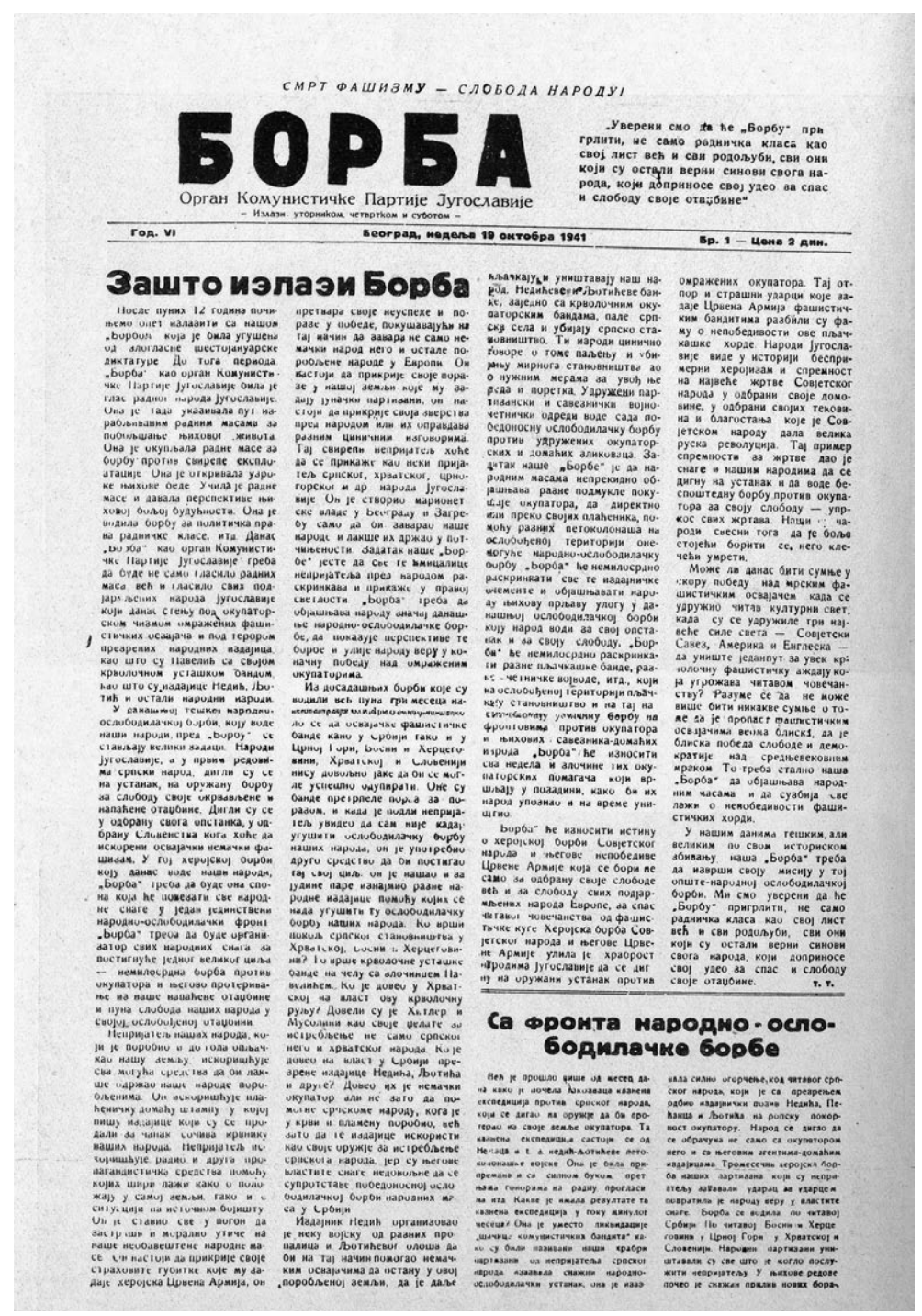

Slika 1. Faksimil prve stranice prvog broja Borbe, tiskan 19. listopada 1941. u Užicu, s uvodnim Titovim člankom „Zašto izlazi “Borba”

Među prvim radovima u kojima je Tito pisao o Drugome svjetskom ratu nalazi se njegov politički referat na Petoj zemaljskoj konferenciji (jesen 1940.), koji se dobrim dijelom bavio upravo poviješću KPJ te jedan članak objavljen u glasilu CK KPH Srp i čekić. ${ }^{18}$ Prvi tekstovi nastali nakon Travanjskog rata i okupacije Jugoslavije objavljeni su dok je Tito još boravio u Zagrebu i Beogradu. Radilo se o nekoliko članaka objavljenih u Proleteru (tekst o savjetovanju KPJ održanom u svibnju 1941. u Zagrebu koji, zanimljivo, nije bio uvršten 
u zbirku Borba za oslobođenje Jugoslavije) ${ }^{19}$ i Biltenu Glavnog štaba (dva teksta u kojima je na sebi svojstven način komentirao prilike u Srbiji nakon osnivanja Nedićeve vlade te jedan u kojemu se bavio osnivanjem i zadacima narodno-oslobodilačkih odbora). ${ }^{20} \mathrm{U}$ to je vrijeme Tito sastavio i dva poznata proglasa - jedan od 22. lipnja 1941., a drugi od 4. srpnja 1941. - koji su u ime CK KPJ upućeni „narodima Jugoslavije” s pozivom na oružanu borbu. ${ }^{21}$

Sredinom rujna Tito je napustio Beograd i otišao na oslobođeni teritorij zapadne Srbije, nastanivši se nedugo potom u Užicu. U tom su razdoblju nastala tri važnija teksta objavljena u Biltenu Glavnog štaba ${ }^{22}$ i užičkoj seriji Borbe. ${ }^{23}$ Izdvaja se prikaz savjetovanja u Stolicama: Tito je tu izrazito optimistično gledao na razvoj ustanka u Srbiji i Bosni i Hercegovini („položaj okupatora u Srbiji je očajan”, „njemačke fašističke bande se ne usuđuju da izlaze iz gradova" itd. ${ }^{24}$ ), dok je istodobno isticao slabosti partizanskog pokreta u Hrvatskoj i Sloveniji. Opisujući u članku Komunistička partija Jugoslavije u današnjoj narodno-oslobodilačkoj borbi „aprilsku narodnu katastrofu”, Tito je posebno apostrofirao izdaju političke elite i višeg komandnog kadra, a kao kontrast opisao držanje KPJ i nabrojio njezine dotadašnje zasluge. ${ }^{25} \mathrm{U}$ oba je ova teksta Tito posvetio veliku pozornost nastojanjima partije da $\mathrm{u}$ Hrvatskoj, Bosni i Hercegovini i Srbiji „osujeti bratoubilačku borbu” i stvara „bratstvo i jedinstvo naroda Jugoslavije”. Druga važna točka bio je popis „izdajnika” među koje je Tito uvrstio Antu Pavelića u Hrvatskoj te, kao i u ranijim člancima, Milana Nedića, Demetrija Ljotića i Kostu Pećanca u Srbiji (no još ne i Dražu Mihailovića). ${ }^{26}$

Nakon sloma Užičke republike krajem studenog 1941., u njemačkoj operaciji koju su partizani naknadno prozvali „Prvom neprijateljskom ofenzivom”, Tito se $s$ Vrhovnim štabom i šačicom preostalih boraca povukao u Sandžak. Otuda se pred njemačkim snagama („Druga neprijateljska ofenziva”) povukao na tromeđu Bosne, Srbije i Crne Gore i početkom 1942. utaborio u Foči, nadajući se povratku u Srbiju. U drugoj polovici travnja započela je nova njemačko-talijanska operacija („Treća neprijateljska ofenziva”), zbog koje su se partizani morali povući prema Crnoj Gori. Zbog teškog položaja u kojemu su se našle partizanske snage, Vrhovni je štab u lipnju 1942. donio odluku da se s preostalim borcima uputi u pohod na zapad, prema Bosanskoj krajini, gdje je ustanak u međuvremenu dobio na zamahu. ${ }^{27}$

Upravo u Titovim tekstovima nastalima u razdoblju kada je partizanski pokret doživljavao neke od najtežih udaraca, iskazuje se najveći manjak optimizma, a između redaka može se pročitati i sva težina stanja u kojemu se našao partizanski pokret - iako se i u kasnijim tekstovima spominju teške borbe, u njima prikaz nije ni izbliza tako dramatičan. Izdvajaju

19 Josip BROZ TITO, „Savjetovanje Komunističke partije Jugoslavije”, Izbor iz djela. Knj. 2: Radnička klasa i Savez komunista Jugoslavije 1926-1977, (ur. Muhamed Filipović), Sarajevo 1979., 137.-147.

20 To su tekstovi: „Zadatak narodno-oslobodilačkih partizanskih odreda (Bilten GŠ NOPOJ, 1/1941.), ,Još jedna izdajnička marionetska vlada” (Bilten GŠ NOPOJ, 4/1941.) i „Teror fašističkih bandita” (Bilten GŠ NOPOJ, 5/1941.). Vidi: Bilten VŠ, 11.-13., 37.-39., 47.-49., 657.

21 Prema: J. BROZ TITO, Opštenarodna odbrana i društvena samozaštita, (ur. Mirza Fililpović), Sarajevo 1980., $56 .-66$. Također: ISTI, Autobiografska kazivanja, drugi tom, Beograd 1983., 260.-261.

22 Članak: „Savjetovanje predstavnika štabova i komandanata narodno-oslobodilačkih partizanskih odreda Jugoslavije”, Bilten V̌́, 7-8/1941., 71.-74.

23 Članci: „Zašto izlazi Borba?” (Borba, 1/1941.) i „Komunistička partija Jugoslavije u narodno-oslobodilačkoj borbi” (Borba, 8-9/1941.). Nakon što je u doba Šestosiječanjske diktature zabranjena, Borba je počela ponovo izlaziti u Užicama u listopadu 1941. Prema: J. BROZ TITO, Borba za oslobođenje Jugoslavije, 1945.2, 25.-32., 245.

24 Isto, 20.-24. „Savjetovanje predstavnika štabova i komandanata narodno-oslobodilačkih partizanskih odreda Jugoslavije".

25 Isto, ,Komunistička partija Jugoslavije u današnjoj narodno-oslobodilačkoj borbi”, 29.-32.

26 Isto, 20.-32.

27 Prema: Jože PIRJEVEC, Tito in tovariši, Ljubljana 2011., 107.-115. 
se tekstovi Komunistička partija $i$ ko su sve saveznici okupatora, Narodno-oslobodilačka borba i organizaciono pitanje naše partije i Jedinstvo narodnih izroda..$^{28}$ Pripovijest koju u njima oslikava Tito je mračna: partizanski odredi morali su se povući iz Srbije, pretrpjevši velike gubitke, osobito među članovima partije. Zajedno s partizanskim odredima, iz Srbije su se povukli i članovi partije, pa su tako s teritorijem izgubljena i partijska uporišta. Za razliku od savjetovanja u Stolicama gdje je isticao kako je KPJ uspjela spriječiti međusobno ubijanje jugoslavenskih naroda, sada je s puno više pesimizma navodio kako su okupatori „uspjeli da zavade Srbe, Hrvate i muslimane”, a u zemlji se rasplamsao „bratoubilački rat”. "29 Štoviše, ovakav je razvoj događaja Tito prvi puta opisao kao gradanski rat, a među „suradnike okupatora” sada je uvrstio i Dražu Mihailovića te neke „reakcionarne elemente u vodstvima građanskih stranaka". ${ }^{30}$

U sličnom tonu, ali s fokusom na unutarpartijska pitanja, Tito je pisao i u članku $\mathrm{Na}$ rodno-oslobodilačka borba i organizaciono pitanje naše partije (Proleter, travanj 1942.). S obzirom da se radilo o tekstu ponajprije namijenjenom partijskom članstvu, Tito je u njemu detaljnije prikazao ulogu KPJ u razdoblju dizanja ustanka. Zbog velikih gubitaka, upozoravao je na potrebu čuvanja partijskih kadrova: u devet mjeseci borbe poginulo je, kako navodi, 3000 članova KPJ, između sedam i deset tisuća članova SKOJ-a te više od 20 članova Centralnog komiteta (KPJ, KPS, KPH). ${ }^{31}$ Konačno, Tito je upozorio partijsko članstvo da se „strogo pridržava linije partije, da se, ni pod koju cijenu, ne da skrenuti (...) sa linije narodno-oslobodilačke borbe”. ${ }^{32}$ Ovo upozorenje treba shvatiti u kontekstu tzv. „lijevih skretanja" koja su se početkom 1942. pojavila u nekim dijelovima Jugoslavije, ponajprije u Crnoj Gori i istočnoj Hercegovini, te nanijela znatnu štetu partizanskom pokretu. ${ }^{33} \mathrm{O}$ tome je Tito govorio i koji mjesec kasnije (lipanj 1942.), kada je prilikom osnivanja IV. crnogorske brigade izjavio kako su „naši ljudi počinili puno grešaka, i neke od njih su nam se ljuto osvetile". ${ }^{34}$ Konačno, radilo se i o depeši Kominterne od 5. ožujka 1942. u kojoj su jugoslavenski komunisti prozvani zbog zaoštravanja klasne borbe („dobija se utisak da sa izvesnim pravom pristalice engleske i jugoslovenske vlade sumnjanju da partizanski pokret dobiva komunistički značaj i da se usmerava prema sovjetizaciji Jugoslavije" ${ }^{35}$ ). Jugoslavenski je komunistički vrh upozoren da vodi računa o međunarodnom položaju SSSR-a unutar antifašističke koalicije i da se usredotoči na oblikovanje zajedničkog narodnog fronta sa svim antihitlerovskim snagama. Stoga je početkom travnja u Politbirou zacrtan novi politički smjer kojim je osnažena orijentacija na „narodno-oslobodilačku borbu”, a što se zrcali i iz navedenih redaka. ${ }^{36}$

\footnotetext{
$\overline{28}$ Radi se o sljedećim tekstovima: „Godišnjica Crvene armije” (posebna brošura iz veljače 1942.), „Komunistička partija i ko su sve saveznice okupatora” i „Narodno-oslobodilačka borba i organizaciono pitanje naše partije” (Proleter, br. 14-15/1942.), „Jedinstvo narodnih izroda” (Bilten VŠ, br. 14-15/1942.), „Govor na dan osnivanja IV. crnogorske brigade" (objavljen u listu Četvrte brigade i Dedijerovom Dnevniku). Ovdje citirano prema: J. BROZ TITO, Borba za oslobodenje Jugoslavije, 1945. ${ }^{2}$, 33.-76., 246.-247.

29 Isto, 56., 63.-64. „Narodno-oslobodilačka borba i organizaciono pitanje naše partije”.

30 Isto, 43.-51. „Komunistička partija i ko su sve saveznici okupatora”.

31 Isto, 53.-62., 65. „Narodno-oslobodilačka borba i organizaciono pitanje naše partije”.

32 Isto, 55.

33 Vidi npr. Mira ŠUVAR, Vladimir Velebit: svjedok historije, Zagreb 2001., 272.-274. Također: Dušan BILANDŽIĆ, Hrvatska moderna povijest, Zagreb 1999., 138.-140.; J. PIRJEVEC, Tito in tovariši, 109.-112.

34 J. BROZ TITO, Borba za oslobođenje Jugoslavije, 1945. ${ }^{2}, 70$. „Govor na dan osnivanja Četvrte crnogorske brigade”.

35 Citirano prema: Vladimir DEDIJER, Josip Broz Tito: prilozi za biografiju, Zagreb 1952., 324.

36 Usp. Povijest Saveza komunista Jugoslavije, Beograd 1985., 213.-215.
} 
U svojim je tekstovima do sredine 1942. Tito u više navrata tematizirao događaje u logoru Kerestinac u ljeto 1941, što je tada okarakterizirao kao „najstrašniji udarac” nanesen partiji. ${ }^{37} \mathrm{U}$ jesen 1941. pisao je o pogibiji „90 naših boraca”, a poimence naveo Ognjena Pricu, Boždara Adžiju, Andriju Žaju, Otokara Keršovanija i Augusta Cesarca (ne npr. i Zvonimira Richtmana, jednog od ključnih protagonista i protivnika u sukobu na ljevici). ${ }^{38}$ Tada je za pokolj teretio samo „ustaške bandite”, no poslije je proširio krug onih koje je držao izravno ili neizravno odgovornima. U proljeće 1942. za tragediju u Kerestincu optužio je i vodstvo HSS-a: ono je dalo zatvoriti „najbolje sinove hrvatskog naroda”, a potom ih izručilo ustašama. To za Tita nije bila slučajnost, već „zločinački smišljeni plan da se istrijebe najbolji radnički borci, a da se pokuša da se sa sebe skine odgovornost". ${ }^{39}$ Istovremeno je za „ovaj strašan udarac našoj pariji” teretio i zagrebačku partijsku organizaciju jer nije na vrijeme poduzela mjere da se „sklone kompromitirani drugovi”, a potom je „aljkavo i neodgovorno" pripremala njihovo oslobađanje. ${ }^{40}$ Ipak, u svojim kasnijim tekstovima taj događaj više nije spominjao, pa ni u referatu na Petom kongresu gdje je također govorio o greškama hrvatskog rukovodstva, no baveći se isključivo Andrijom Hebrangom.

U srpnju 1942. Tito je s Vrhovnim štabom i nekoliko brigada stigao u Bosansku krajinu gdje su već od proljeća 1942. borbe dobile na intenzitetu. U Titovoj kasnijoj interpretaciji, upravo je dolazak tih jedinica imao „veliki značaj po dalji razvitak ustanka ne samo za Bosansku Krajinu i Dalmaciju, nego i za Hrvatsku i Sloveniju”. ${ }^{41}$ U to se vrijeme navršila i godina dana od poziva KPJ na ustanak pa je Tito tom prigodom napisao članak Godišnjica narodno-oslobodilačke borbe u Jugoslaviji. ${ }^{42}$ Bio je to prvi njegov članak nakon odlaska s tromeđe, a ujedno i prvi „povijesni” tekst u kojemu je rekapitulirao dotadašnji tijek rata na jugoslavenskom prostoru i time izravno oblikovao pripovijest o NOB-u. Tito je ostao u Bosni - na raznim lokacijama na području Bihaća, oko Neretve i Sutjeske, Jajca i Drvara - sve do svibnja 1944. kada je, u vrijeme operacije Konjićev skok („Sedme neprijateljske ofenzive"), bio prisiljen napustiti Drvar i skloniti se na Vis. Na Visu je ostao do rujna 1944., kada je otputovao u Moskvu kako bi sa Staljinom dogovorio zajedničke operacije NOVJ i Crvene armije u Srbiji.

Upravo u razdoblju od dolaska u Bihać do dolaska na Vis nastali su i neki od Titovih najznačajnijih i najcitiranijih radova u kojima je (re)konstruirao uzroke i tijek rata, oblikovao planove za budućnost te istovremeno formulirao osnove narativa o NOB-u. Ti su se tekstovi poslije tiskali u velikim tiražama i snažno utjecali na oblikovanje slike o ratu: $\mathrm{Na}$ cionalno pitanje u Jugoslaviji u svjetlosti narodno-oslobodilačke borbe" koji je Tito namijenio „najširim masama naroda” (Proleter, br. 16 iz prosinca 1942.); Peta neprijateljska ofenziva (Bilten VŠ, br. 29-31 za lipanj, srpanj i kolovoz 1943.); Razvitak oslobodilačke borbe u vezi $s$ medunarodnim dogadajima, odnosno referat na Drugom zasjedanju AVNOJ-a (posebna

37 J. BROZ TITO, Borba za oslobođenje Jugoslavije, 1945. ${ }^{2}$, 56. „Narodno-oslobodilačka borba i organizaciono pitanje naše partije".

38 Isto, 31. „Komunistička partija Jugoslavije u današnjoj narodno-oslobodilačkoj borbi”.

39 Isto, 45.-46. „Komunistička partija i ko su sve saveznici okupatora”.

40 Isto, 56. „Narodno-oslobodilačka borba i organizaciono pitanje naše partije”. Tito je u svojem članku spomenuo i „nezdravo stanje” koje je postojalo u zagrebačkoj partijskoj organizaciji zbog „uplitanja nekih ljudi sa strane”, najvjerojatnije referirajući na Josipa Kopiniča. Zbog kerestinačke tragedije provedena je partijska istraga nakon koje su ukorom kažnjeni pojedini članovi CK KPH i cijeli Mjesni komitet u Zagrebu. Više u: Ivan JELIĆ, Tragedija u Kerestincu: zagrebačko ljeto 1941., Zagreb 1986., 122.-143.

41 J. BROZ TITO, Borba za oslobođenje Jugoslavije, 1945. 2, 205. „Borba naroda porobljene Jugoslavije”.

42 Isto, 73.-76. „Godišnjica narodno-oslobodilačke borbe u Jugoslaviji”. 
brošura iz 1943.); Značaj odluka AVNOJ-a za daljnji razvoj naše borbe i stvaranje federativne državne zajednice (Nova Jugoslavija, br. 1 iz ožujka 1944.). Izdvaja se i članak Borba naroda porobljene Jugoslavije (Nova Jugoslavija, br. 6 iz svibnja 1944.) koji je pisan za američki tisak, a potom tiskan kao brošura na raznim jezicima (engleskom, ruskom, francuskom, talijanskom). S obzirom da je tekst bio namijenjen inozemnom čitateljstvu, ponajviše onome na Zapadu, Tito je u njemu spomenuo KPJ samo na početku, kada opisuje kako je došlo do poziva na ustanak. Potom je, opisujući donošenje odluka, uglavnom referirao na Vrhovni štab, AVNOJ, narodno-oslobodilačke odbore itd. Podjednako, u tom je tekstu umjesto naziva „proleterske brigade” koristio naziv „I. i II. srpska brigada” pa valja pretpostaviti kako je izbjegavao termine koji bi mogli poticati asocijacije na revolucionarne težnje u trenutku kada se od saveznika nastojalo steći međunarodno priznanje političkih zasada NOB-a. ${ }^{43}$

U razdoblju između listopada 1944. (odnosno, povratka u Beograd) i izbora za Ustavotvornu skupštinu u studenom 1945. godine, Tito je u nekoliko izlaganja i prigodnih govora prikazao razdoblje od ljeta 1944. do kraja rata, izložio svoje ocjene o tek minulom ratu ili govorio o budućem uređenju Demokratske Federativne Jugoslavije. ${ }^{44}$ U nastavku teksta, navest ću neke od ključnih i dugotrajnih obrazaca i predodžbi o „Narodnooslobodilačkoj borbi” koje su ovi Titovi tekstovi ostavili u nasljeđe, a koji se na ovaj ili onaj način perpetuiraju do danas.

\section{Slika o prvoj Jugoslaviji}

Josip Broz Tito je u svojim tekstovima izgradio izrazito negativnu sliku o „versajskoj Jugoslaviji” koja je imala kontrastivnu funkciju: potreba za stvaranjem „nove” Jugoslavije objašnjavala se nedostacima i promašajima one „stare”. Ovakav je prikaz čitateljima trebao omogućiti da razumiju zašto „nema povratka na staro” - tom su se sintagmom nagoviještale promjene u jugoslavenskoj državi i društvu, a binom staro-novo zapravo se koristio umjesto izraza revolucija koji se tada, barem ne javno, još nije upotrebljavao.

U Titovim je tekstovima prva Jugoslavija („rođena na Krfu, u Londonu i Parizu”) opisana kao „najtipičnija zemlja nacionalnog ugnjetavanja”, korupcije i socijalne nepravde. U njoj je vladala ,jedna brojčano neznatna manjina velikosrpskih hegemonista” koja je stvorila „režim žandarma, režim glavinjača, režim socijalnog i nacionalnog bespravlja”. ${ }^{45}$ Važno mjesto u tom narativu imao je slom Jugoslavije u Travanjskom ratu, koji je Tito opisao poslije često korištenom sintagmom o „najsramnijim danima u historiji naših naroda". ${ }^{46}$ Objašnjavanje uzroka sloma imalo je ključnu ulogu: njih je Tito sažeo u izlaganju na Drugom zasjedanju AVNOJ-a i u članku Borba za oslobođenje Jugoslavije. Na prvom mjestu naveo je „dvadesetogodišnje ugnjetavanje naroda Jugoslavije (kao što su Hrvati, Make-

\footnotetext{
Isto, 187.-215. „Borba naroda porobljene Jugoslavije”.

44 Npr. ekspoze na Trećem zasjedanju AVNOJ-a (8. 8. 1945.) te govori na Beogradskom radiju prilikom obilježavanja Dana pobjede (9. 5. 1945.), na osnivačkom kongresu KP Srbije (12. 5. 1945.), na mitingu u Zagrebu (21. 5. 1945.), u Ljubljani (27. 5. 1945.), u Beloj Crkvi prigodom prve proslave Dana ustanka u Srbiji (7. 7. 1945.), na Prvom kongresu Narodnog fronta Jugoslavije (7. 8. 1945.), na zboru oficira vojske Kraljevine Jugoslavije u Zemunu koji su se vratili iz ratnog zarobljeništva (16. 10. 1945.) itd.

45 Isto, 122.-123. „Nacionalno pitanje u Jugoslaviji u svjetlosti narodno-oslobodilačke borbe”.

46 Isto, 188. „Borba naroda porobljene Jugoslavije”.
} 
donci, Slovenci i drugi) od šake velikosrpskih hegemonista". ${ }^{47}$

Kao drugi uzrok istaknuo je „nečuvenu korupciju” vladajućih krugova („najviše u vojnom ministarstvu") te njihovo povezivanje „sa najreakcionarnijim krugovima - a naročito njemačkim i italijanskim - u cilju održanja na vlasti”.

Konačno, a možda i najvažnije, Tito je u svim svojim ratnim tekstovima isticao „nečuveno izdajništvo” političke i vojne elite: u generalštabu su sjedili ,izdajnici Nedićeva tipa" koji su se nalazili u službi Nijemaca, dok su „kralj i vlada, zajedno s grupom ljudi koji su bili odgovorni za takvu sudbinu, pobjegli u inostranstvo." ${ }^{38}$ Opisujući ishod ovih događaja, Tito je upotrijebio još jednu sintagmu koja se poslije često upotrebljavala: nakon kapitulacije „nastali su najstrašniji dani koji su ikada postojali u historiji naših naroda". ${ }^{49}$ "Jugoslavija je bila raskomadana", a u zemlji je "nastao nečuven teror i istrebljivanje ne samo najnaprednijih ljudi, nego istrebljivanje čitavog srpskog stanovništva u $\mathrm{Hr}$ -

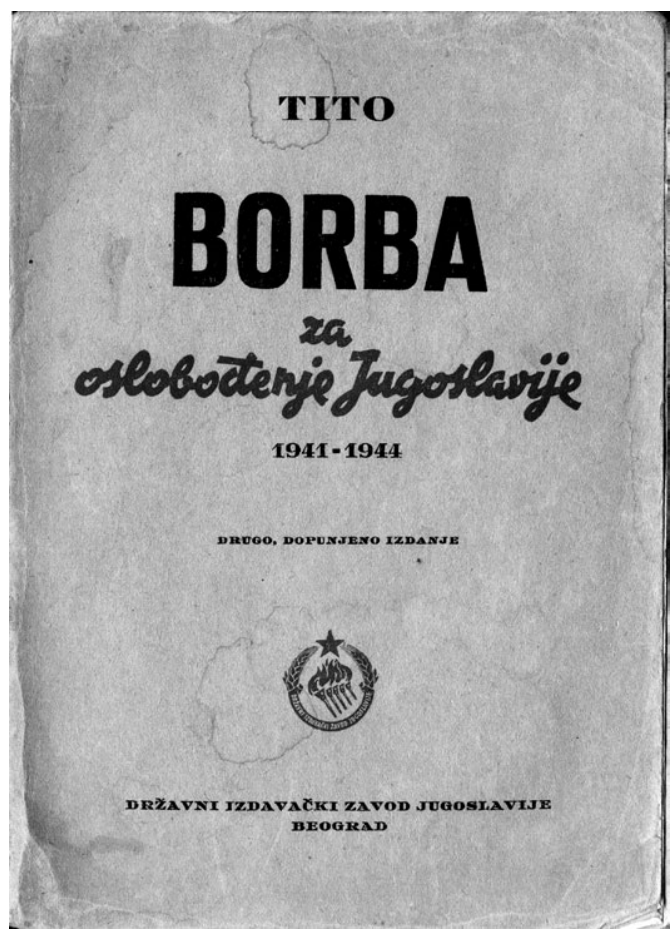

Slika 2. Naslovnica drugog izdanja knjige Borba za oslobodenje Jugoslavije (1945.) vatskoj, Bosni i Hercegovini, Vojvodini, slovenačkog stanovnišstva u Sloveniji itd.”. 50

\section{2. „Ustanak naroda Jugoslavije”}

Izdaji, porazu, kapitulaciji i okupaciji, kao i tragičnim događajima koji su uslijedili, Tito je suprotstavio prikaz „ustanka naroda Jugoslavije” kao ključne sastavnica narativa o NOBu. Snažno naglašavanje izdaje vojnog i političkog vrha, kao i naglašavanje da je u tim tragičnim trenucima samo KPJ ostala uz narod, bili su jedno od ishodišta na kojemu je partija temeljila svoj poslijeratni legitimitet. Odnosno, Titovim riječima na Drugom zasjedanju AVNOJ-a, ,jedino je Komunistička partija bila ta koja je povela narod na oružani ustanak, koja nije klonula duhom, već je visoko digla zastavu oslobodilačke borbe". ${ }^{51}$

Sam termin „narodni ustanak” koristio se već vrlo rano - u prvom broju Biltena Glavnog štaba njime se opisivao spontani ustanak srpskog stanovništva u Lici nad kojim su komunisti tek trebali preuzeti nadzor („,predlažemo štabovima tih oblasti da odmah

\footnotetext{
Isto, 156.-157. „Razvitak oslobodilačke borbe u vezi s međunarodnim događajima”.

48 Isto, 30., 156.-157., 187.-188. „Borba naroda porobljene Jugoslavije”.

49 Isto, 189.

50 Isto, 157. „Razvitak oslobodilačke borbe u vezi s međunarodnim događajima”.

51 Isto, 157. „Razvitak oslobodilačke borbe u vezi s međunarodnim događajima” i 30.-31. „Komunistička partija Jugoslavije u današnjoj narodno-oslobodilačkoj borbi”.
} 
organizuju pobunjene mase”). ${ }^{52}$ No, upravo su Titovi tekstovi pridonijeli stvaranju uobličene pripovijesti u kojoj se ustanak počeo jasno vezivati uz inicijativu KPJ te prikazivati kao rezultat pažljivo osmišljenog i dobro pripremljenog plana Centralnog komiteta. Taj se plan, kako je isticao Tito, počeo oblikovati još i prije nego što je Jugoslavija okupirana i raskomadana: komunisti su još od Anschlussa „signalizirali na opasnost”, „upozoravali na rad pete kolone" i ,pozivali na okup sve čestite rodoljube" (na tragu Kominternine linije „narodnog fronta”). Čim je započeo Travanjski rat komunisti su „stupili u prve borbene redove”, a Partija je iz „aprilske narodne katastrofe” izvukla pouke za daljnji rad i „u ovim najtežim danima historije naših naroda (...) stavila se na čelo narodne borbe". ${ }^{33}$ Valja napomenuti i ono čega nije bilo: demonstracije 27. ožujka 1941. u Titovim su ratnim tekstovima opisane kao ,jedna od svjetlijih točaka u historiji našeg naroda”, no nisu se još izravno pripisivale inicijativi KPJ - tek je u izlaganju na Petom kongresu Tito izjavio kako je partija toga dana „bila potpuni gospodar situacije”..$^{4}$

Početak „narodnog ustanka” Tito je najjasnije prikazao u članku Borba naroda porobljene Jugoslavije: na dan „kad su njemačke horde iznenada napale Sovjetski Savez”, vodstvo KPJ hitno je održalo sjednicu i donijelo odluku da se započne s ustankom. Na istoj je sjednici Vojna komisija, osnovana još u jesen 1940. godine, proširena i preimenovana u Glavni (kasnije Vrhovni) štab. Glavni je štab (odnosno Politbiro, kao što je to Tito jasno istaknuo u referatu na Petom kongresu) potom poslao svoje članove u različite dijelove Jugoslavije, sa zadatkom da organiziraju partizanske odrede i preuzmu vodstvo nad njihovim djelovanjem. Tako je 22. lipnja od početka imao dvostruki značaj - nije se vezivao samo uz njemački napad na SSSR, već i uz odluku da se (na poziv Kominterne) započne s ustankom. U svim je analiziranim Titovim tekstovima taj datum prikazivan kao prekretnica u razvoju ustanka (zanimljivo, uopće se ne spominje 4. srpnja, datum koji će 1956. biti ustoličen kao Dan ustanka naroda Jugoslavije ${ }^{55}$ ): do napada na SSSR bilo je akcija po gradovima i borbi „tu i tamo” u bosanskim i hercegovačkim brdima, no poslije napada na SSSR „partizanski pokret počeo se naglo širiti u svim ostalim dijelovima zemlje”..$^{66}$ Odluku o ranom dizanju ustanka Tito je objašnjavao i opravdavao nužnošću da se preduhitre „paklene namjere” okupatora da zavadi jugoslavenske narode i potakne bratoubilački rat. ${ }^{57}$

U člancima nastalima tijekom 1941. i 1942. (npr. u prikazu savjetovanja u Stolicama i Godišnjici narodnooslobodilačke borbe u Jugoslaviji) Tito je opisao razvoj ustanka po pojedinim područjima, što je poslužilo kao model i u kasnijim znanstvenim i popularnim prikazima i udžbenicima, a s vremenom će postati i odraz republičkih narativa u nastajanju. Iz Titovih su radova proizašla još neka pitanja o ustanku koja će kasnije biti predmet žučnih rasprava u jugoslavenskoj historiografiji, odnosno pojedinim republičkim historiografijama. Jedno od njih bio je i redoslijed izbijanja ustanaka koji nije u potpunosti identičan u ranijim i kasnijim tekstovima. Primjerice, u članku Godišnjica narodno-oslobodilačke borbe

\footnotetext{
Bilten VŠ, 165.-167.

53 J. BROZ TITO, Borba za oslobođenje Jugoslavije, 1945.2, 29.-32. „Komunistička partija Jugoslavije u današnjoj narodno-oslobodilačkoj borbi”; 55. „Narodno-oslobodilačka borba i organizaciono pitanje naše partije”; 72. „Govor na dan osnivanja Četvrte crnogorske brigade”; 189.-190. „Borba naroda porobljene Jugoslavije”.

54 Isto, 188. „Borba naroda porobljene Jugoslavije”. ISTI, Politički referat CK KPJ, 33.

55 O tome više u: S. KOREN, Politika povijesti u Jugoslaviji, 357.-359., 449.

56 J. BROZ TITO, Borba za oslobođenje Jugoslavije, 1945. 2, 190.-191. „Borba naroda porobljene Jugoslavije”.

57 J. BROZ TITO, Borba za oslobodenje Jugoslavije, 1945. 2, 214. „Borba naroda porobljene Jugoslavije”.
} 
u Jugoslaviji (ljeto 1942.) Tito je opisao kako su i kojim redoslijedom izbili ustanci u pojedinim dijelovima Jugoslavije:

Na bojni poklič Komunističke partije Jugoslavije dizao se narod u pojedinim krajevima na ustanak. Najprije u Crnoj Gori i Srbiji, onda u Bosni i Hercegovini, pa onda u Hrvatskoj, Dalmaciji i Sloveniji (označila S.K.) dizao se narod u borbu protiv okupatora. ${ }^{58}$

Taj redoslijed nije bio u potpunosti identičan konstruktu koji će biti oblikovan na samom kraju rata, niti se ustanci, kao što je kasnije bio slučaj, povezuju s nekim određenim mjestom (Bela Crkva, Čevo i Virpazar, Kamnik, Drvar, Bosansko Grahovo, Srb, Prilep). Jedino se za Crnu Goru navodi točan datum ustanka - 13. srpnja - koji je kasnije i bio proglašen službenim Danom ustanka u toj republici. Upravo je taj datum zapravo jedini autentični datum ustanka koji se spominje još u prvom broju Biltena Glavnog štaba iz kolovoza 1941. - svi su ostali naknadno konstruirani, i to najvjerojatnije negdje na samom kraju rata, neposredno prije nego su se počeli obilježavati kao republički praznici. ${ }^{59}$ No, u kasnijim Titovim tekstovima izvršena je inverzija u redoslijedu ustanaka, što se može zamijetiti u izlaganju na Drugom zasjedanju AVNOJ-a (1943):

Počeli su se stvarati partizanski odredi, najprije u Srbiji, Bosni i Hercegovini, pa onda opći narodni ustanak u mjesecu julu u Crnoj Gori (označila S.K.), zatim širenje partizanskog pokreta u Hrvatskoj, Sloveniji itd. ${ }^{60}$

Potom je taj redoslijed dobio posve oblikovani izgled u članku Borba naroda porobljene Jugoslavije (1944.), gdje je više-manje ugotovljen onaj redoslijed koji će se kasnije iskazati i kroz republičke datume ustanaka. Ovdje je opis događaja proširen i izmijenjen i, što je još važnije, s posve drugačijim fokusom: sada je, za razliku od teksta iz 1942. godine, u središtu pripovijesti Vrhovni štab i sam Tito. Iako se ni ovdje ne spominju datumi i mjesta ustanka, izvršena je još jedna inverzija u prikazu redoslijeda izbijanja borbi: prvo se opisuje djelovanje prvih partizanskih odreda na tlu Srbije, onda slijedi opis ustanka u Crnoj Gori, pa u Bosni i Hercegovini i drugim područjima. ${ }^{61} \mathrm{U}$ novom kronološkom redoslijedu tako se najvjerojatnije ogledala potreba i nastojanje da se naglasi uloga Vrhovnog štaba, Politbiroa CK KPJ i samog Tita koji su se tada nalazili na tlu Srbije, pa je bilo „logično” da je „prva ustanička puška pukla" upravo tamo gdje su se nalazili Tito i središnja tijela.

Drugo pitanje koje je proizašlo iz Titovih ratnih tekstova jest kada se u pojedinim krajevima rasplamsao ustanak. Tito je u ranim tekstovima osobito isticao zasluge srpskog naroda za ustanak, ${ }^{62}$ a istovremeno kritizirao zaostajanje ustanka u Hrvatskoj i Sloveniji. U jesen 1941. entuzijastično je opisao djelovanje partizanskih odreda u Srbiji, Bosni i Hercegovini, Crnoj Gori te među srpskim stanovništvom na Kordunu i Lici. No, ukazao je i na slabosti partizanskog pokreta u Hrvatskoj istaknuvši da obuhvaća „vrlo mali broj Hrvata-seljaka”, kao i da partizanski odredi „nemaju dovoljno potpore od hrvatskog stanovništva”. U istom je tekstu zbog grešaka prozvao i „,lovenske drugove” jer im još „nije

\footnotetext{
Isto, 73. „Godišnjica narodno-oslobodilačke borbe u Jugoslaviji”.

O tome više u: S. KOREN, Politika povijesti u Jugoslaviji, 362.-363., 392.-402.

60 J. BROZ TITO, Borba za oslobođenje Jugoslavije, 1945.2, 157. „Razvitak oslobodilačke borbe u vezi s međunarodnim događajima”.

${ }_{61}$ Isto, 187., 215. „Borba naroda porobljene Jugoslavije”.

62 Isto, 25. „Zašto izlazi Borba”.
} 
pošlo za rukom da uspješno povedu slovenski narod u borbu". ${ }^{63}$ Slično je pisao i početkom 1942. godine, kada je prozvao hrvatske komuniste da su najmanje učinili u pogledu ustanka, a hrvatski narod ponovo pozvao da „opere sramotu koju mu je nanio zlikovac Pavelić sa svojim ustašama” i povede borbu „rame uz rame sa srpskim, crnogorskim, slovenskim i drugim narodima Jugoslavije". ${ }^{64}$

No, već u ljeto 1942. Titove ocjene ustanka bitno su se izmijenile. U međuvremenu je ustanak u Srbiji doživio slom, a rasplamsao se na području Bosanske krajine, Like i sjeverne Dalmacije. To je jasno došlo do izražaja u članku Godišnjica narodno-oslobodilačke borbe u Jugoslaviji gdje je Tito opisao ustanak u Srbiji i Crnoj Gori kao neuspješan: ustanak u Crnoj Gori bio je više „stihijskog karaktera”, pa je „privremeno ugušen”, a u Srbiji su uz pomoć „izroda srpskog naroda njemački osvajači uspjeli da ponovo okupiraju veći dio oslobođene Srbije". Istovremeno je ublažio opaske o kašnjenju ustanka u Hrvatskoj i Sloveniji: iako i dalje navodi da se partizanski pokret u Hrvatskoj razvijao „nejednomjerno i dosta sporo", sada ističe i kako je na tom području narodno-oslobodilačka borba od samog početka dobila „trajan i čvrst karakter, slično Srbiji, iako dosta kasnije”, dok je u Sloveniji već u ljeto 1942. poprimila „karakter općeg narodnog ustanka”. Iako je i dalje spominjao da je u partizanskim odredima u Hrvatskoj dugo vremena bilo malo Hrvata (s iznimkom Dalmacije i Primorja „gdje su partizanski odredi stvoreni od samih Hrvata”), istaknuo je i kako se sada „opaža snažna prekretnica, jer se skoro po čitavoj Hrvatskoj stvaraju odredi od hrvatskog stanovništva”, a NOB se postupno pretvara u „opći narodni ustanak sa velikim izgledima na uspjeh". ${ }^{65}$ Konačno, u referatu na Drugom zasjedanju AVNOJ-a konstatirao da je nakon kapitulacije Italije došlo „do neviđenog poleta narodnog ustanka u Sloveniji, Dalmaciji, pa i u ostaloj Hrvatskoj”, tako da „danas nema više ni jedne oblasti u Jugoslaviji gdje se nije rasplamsao plamen narodnog ustanka". ${ }^{66}$

Zamjetno je također da se u ovim tekstovima ustanak u Makedoniji, ni Makedonija sama, uopće ne spominju. Tito je prvi puta spomenuo situaciju u Makedoniji tek u referatu na Drugom zasjedanju AVNOJ-a, navodeći da su ,u posljednje vrijeme” partizanske snage tamo postigle „znatne uspjehe”. ${ }^{67}$ Tek je naknadno, u članku Borba za oslobodenje Jugoslavije (1944.) napomenuo kako je u jesen 1942. Vrhovni štab poslao u Makedoniju ,jednog svog člana" (Svetozara Vukmanovića Tempa) da tamo organizira partizanske odrede. Ni u jednom tekstu nije spomenuo Šatorova i njegovu ulogu u Makedoniji - za to je ipak trebalo pričekati politički referat na Petom kongresu KPJ 1948. godine. ${ }^{68}$

Ove su Titove ocjene o razvoju ustanka ostale predmetom rasprava, pa i izvorom nesuglasica, tijekom cijelog postojanja socijalističke Jugoslavije. Nije se, naravno, radilo samo o pitanju kada se razvio masovni ustanak, već o zaslugama pojedinih republika/naroda za pobjedu u ratu, a ta je rasprava ujedno bila i jedan od ispušnih ventila kroz koji su se iskazivale međunacionalne tenzije, osobito od početka 1960-ih nadalje. U tom kontekstu valja,

$\overline{63}$ Isto, 20., 22.-23. „Savjetovanje predstavnika štabova i komandanata narodno-oslobodilačkih partizanskih odreda Jugoslavije".

64 Isto, 52. „Komunistička partija i ko su sve saveznici okupatora”.

65 Isto, 75. „Godišnjica narodno-oslobodilačke borbe u Jugoslaviji”.

66 Isto, 162. „Razvitak oslobodilačke borbe naroda Jugoslavije u vezi sa međunarodnim događajima”.

67 Isto.

68 Isto, 162.-163. „Razvitak oslobodilačke borbe naroda Jugoslavije u vezi sa međunarodnim događajima” i 205. „Borba naroda porobljene Jugoslavije”. Josip BROZ TITO, Politički izvještaj Centralnog komiteta Komunističke partije Jugoslavije: referat održan na Vkongresu KPJ, Beograd 1948., 44., 72.-73. 
primjerice, čitati i izjavu Božidara Novaka na Petom kongresu Saveza komunista Hrvatske 1965. kako „postoje tendencije licitiranja tko je bio 'bolji', a tko 'gori' u ustanku”. ${ }^{99}$

\section{Konstrukt o „sedam neprijateljskih ofenziva”}

Jedno od obilježja Titovih tekstova jest i nastojanje da se izvrši periodizacija ratnih događaja. Dok je u tekstovima iz 1941. i 1942. Tito je najčešće opisivao razvoj NOB-a po pojedinim područjima, u referatu na Drugom zasjedanju AVNOJ-a prvi je puta podijelio dotadašnji tijek rata u četiri etape..$^{70}$ Gotovo istovremeno pojavio se i konstrukt o sedam neprijateljskih ofenziva koji se najvjerojatnije također može pripisati Titu ili krugu oko Tita. Prvi puta se javlja u ljeto 1943. godine, tada još u obliku „pet ofenziva”. Dok je u Biltenu Vrhovnog štaba iz travnja 1943. bitka na Neretvi još opisana kao „velika neprijateljska ofenziva", ${ }^{71}$ već je prvi sljedeći broj Biltena iz kolovoza 1943. otvorio Titov članak Peta neprijateljska ofenziva u kojemu je opisao bitke na Neretvi („Četvrta ofenziva”) i Sutjesci („Peta ofenziva”). ${ }^{72}$ Tito je o pet ofenziva govorio i u svojem referatu na Drugom zasjedanju AVNOJ-a, ponovo se fokusirajući upravo na dvije posljednje. Prikaz po ofenzivama napose je izražen u članku Borba naroda porobljene Jugoslavije u kojemu je Tito opširno opisao prve tri ofenzive, dao još detaljniji prikaz Četvrte ofenzive i začuđujuće šturi prikaz Pete ofenzive. ${ }^{73}$ Šstu i sedmu ofenzivu opisao je general Arso Jovanović u istoimenim tekstovima objavljenima 1944. godine, neposredno nakon tih operacija. ${ }^{74}$

Tito je „neprijateljske ofenzive” opisao živim jezikom, osobito u članku Borba naroda porobljene Jugoslavije. U njegovu su se narativu sve „neprijateljske ofenzive” na ovaj ili onaj način pretvarale u partizansku pobjedu, bilo stoga što su neprijatelju naneseni golemi gubici, zato što neprijatelj nije uspio uništiti partizanske jedinice, ili stoga što su, usprkos privremenom povlačenju, stvoreni uvjeti za jačanje pokreta. ${ }^{75}$ Prikazujući bitku na Neretvi, iznio je neke opise i ocjene koji su potom postali uobičajeni: opisao ju je kao „najveću bitku za ranjenike koja je trajala 40 dana”, kao bitku koja se odvijala u „okolnostima kakvih je bilo malo u historiji ratova” i ,svršila porazno po neprijatelja”. ${ }^{76} \mathrm{U}$ prikazu iz 1944 . detaljno je opisao i „ratnu varku” s rušenjem mostova na Neretvi, što će kasnije postati jedan od ključnih ratnih mitova koji je potom u više navrata prepričavan, opjevan i ekraniziran. ${ }^{77}$

Bitku na Neretvi očigledno je bilo puno lakše prikazati nego bitku na Sutjesci: iako ju je Tito opisao kao „najslavniju epopeju naše NOB-e” te „najtežu i najkrvaviju borbu”, ${ }^{78}$ ipak

69 Peti kongres Saveza komunista Hrvatske. Zagreb, 26 - 29. travnja 1965. Stenografske bilješke, Zagreb 1966., 503.-507.

70 J. BROZ TITO, Borba za oslobodenje Jugoslavije, 1945. ${ }^{2}, 156$. „Razvitak oslobodilačke borbe naroda Jugoslavije u vezi sa međunarodnim događajima”.

71 Bilten VŠ, 23-27/1942-1943.

72 Bilten VŠ, 29-31/1943. Iste je godine objavljena i knjižica Vladimira DEDIJERA Četvrta i Peta Hitlerova ofenziva na partizane Jugoslavije, Kraj Drežnice u šumi Javornici u Gorskom Kotaru, 1943.

73 J. BROZ TITO, Borba za oslobodenje Jugoslavije, 1945. ${ }^{2}$, 187.-215. „Borba naroda porobljene Jugoslavije”.

74 Arso JOVANOVIĆ, Šesta i sedma neprijateljska ofanziva, Beograd 1944.

75 Vidi npr.: J. BROZ TITO, Politički izvještaj CK KPJ, 68.-69.; ISTI, Opštenarodna odbrana i društvena samozaštita, 282.-283. „Ekspoze na Trećem zasjedanju AVNOJ-a”; ISTI, „U čemu je specifičnost oslobodilačke borbe i revolucionarnog preobražaja nove Jugoslavije”, Komunist, 1/1946.

76 J. BROZ TITO, Borba za oslobođenje Jugoslavije, 1945. 2, 145.-147. „Peta neprijateljska ofenziva”.

77 Isto, 209. „Borba naroda porobljene Jugoslavije”.

78 Isto, 145. „Peta neprijateljska ofenziva”. 
u referatu na Drugom zasjedanju AVNOJ-a nije mogao ne spomenuti da su partizanske jedinice na Sutjesci pretrpjele „teške gubitke”. ${ }^{79}$ U članku Borba naroda porobljene Jugoslavije Tito je Petu ofenzivu prikazao iznimno kratko: tek na četvrtini stranice, za razliku od četiri stranice posvećenih Četvrtoj ofenzivi. Od ukupno šest ne pretjerano dugačkih rečenica, prve četiri posvećene su planovima neprijatelja, a potom je sama bitka prikazana lakonski:

„Počela je peta i najžešća bitka, iz koje su naše slavne jedinice, iako s ogromnim žrtvama, ponovno izašle čitave, nanijevši neprijatelju ogromne gubitke. O petoj ofanzivi međunarodna javnost već zna prilično i još će se o tome pisati, pa je ja ovdje neću opisivati." ${ }^{\circ 0}$

Na sličan način Tito je preskočio Petu ofenzivu i u svojem referatu na Petom kongresu KPJ (1948), rekavši da o toj bitki neće govoriti ,jer bi to uzelo isuviše mjesta i vremena” ${ }^{81}$

U kasnijim ratnim tekstovima (npr. Borba naroda porobljene Jugoslavije), kada je narativ o ratu već dobrim dijelom bio uobličen, pripovijedanje kroz sedam ofenziva pogodovalo je prikazu koji je u središtu imao djelovanje skupine oko Vrhovnog štaba te isticao Titovu ulogu i zasluge. Fokus na skupinu oko Vrhovnog štaba ujedno je u prvi plan stavio borbe u Srbiji, Crnoj Gori i Bosni i Hercegovini, dok su se borbe u ostalim dijelovima zemlje spominjale tek usputno i svedene su na nekoliko rečenica. ${ }^{82}$ To je - vrlo vjerojatno od početka, a potom posve jasno (i javno) od početka 1960-ih - bilo uzrok frustracija političkih elita ovih republika, što je primjerice došlo do izražaja prilikom rasprava o knjizi Pregled istorije Saveza komunista Jugoslavije početkom 1960-ih godina. Prikaz rata koji se fokusirao na opisivanje „sedam ofenziva” vrlo je brzo postao dijelom popularnih prikaza rata, udžbenika povijesti i nastavničkih predavanja. No, to je već u 1940-ima, a onda osobito u 1950-ima kada se intenzivirala proizvodnja sjećanja na rat, postalo redovitim i učestalim predmetom pritužaba i nezadovoljstava, od najviših partijskih dužnosnika do prosvjetnih vlasti. Tako je u svakodnevnoj uporabi Titov narativ često sveden na suhoparno nizanje događaja, datuma i „neprijateljskih ofenziva”, a pritom su njegovi korisnici - kako su se požalili sudionici Šestog plenuma CK SKJ 1956. (npr. Petar Stambolić, Aleksandar Ranković, Veljko Vlahović) - dobivali tek „bledu sliku naše revolucije”. ${ }^{83}$

\section{Stvaranje „narodne vojske” i „narodne vlasti”}

Osim kroz opise bitki i ofenziva, vojni aspekt rata bio je u Titovim radovima zastupljen i kroz prikaz stvaranja „Narodnooslobodilačke vojske”, koju je Tito ubrajao u jednu od „najvažnijih tekovina narodnooslobodilačke borbe”. Tito je u nekoliko svojih tekstova

\footnotetext{
9 Isto, 159.-160. „Razvitak oslobodilačke borbe naroda Jugoslavije u vezi sa međunarodnim događajima”.

Isto, 210. „Borba naroda porobljene Jugoslavije”.

81 J. BROZ TITO, Politički izvještaj CKKPJ, 66. Tim će se događajima detaljnije vratiti kasnije, u svojim govorima, sjećanjima i intervjuima. Vidi npr.: V. DEDIJER, Josip Broz Tito: prilozi za biografiju, 345.-349.; ISTI, Novi prilozi za biografiju Josipa Broza Tita, Rijeka 1981., tom I, 562.-564. („Autobiografija Tita”); tom II, 827.-828.; Josip BROZ TITO, Autobiografska kazivanja, prvi tom, Beograd 1983. ${ }^{2}, 361 .-370$.

82 Vidi npr.: J. BROZ TITO, Borba za oslobodenje Jugoslavije, $1945 .^{2}$, npr. u članku „Borba naroda porobljene Jugoslavije”, osobito stranice 199., 204., 205.

83 „Šesti plenum Centralnog komiteta Saveza komunista Jugoslavije, 13-14 mart 1956”, Komunist, 3-4/1956., $149 .-263$.
} 
opisao proces nastajanja „nove narodne armije” od prvih partizanskih odreda do njihova pretvaranja u regularne vojne jedinice (NOVJ) u jesen 1942. i potom u ,veliku narodnu vojsku, koja je pobjedonosno gonila i uništavala omražene fašističke okupatore.” Tito je isticao kako je nova armija zajedno sa svojim rukovodećim kadrom „izrasla iz naroda”, odnosno „stvarala se od golorukih rodoljuba, seljaka, radnika, poštene inteligencije, omladinaca grada i sela, koji su se digli na ustanak, u borbu protiv okupatora i njihovih plaćenika" ${ }^{84}$ Upravo na tom se elementu u početku i temeljio Titov kult, odnosno njegova glavna sastavnica bio je prikaz Tita kao vojskovođe pobjedonosne Jugoslavenske armije. Važno uporišno mjesto činilo je i stvaranje proleterskih brigada - njih se tada obično opisivalo kao jedinice sposobne za veće operacije na širem teritoriju, u odnosu na partizanske odrede koji su djelovali lokalno. To se može povezati i s već spomenutim ukorom koji je početkom ožujka 1942. stigao iz Moskve, kada je vrh KPJ prozvan i zbog osnivanja „posebne proleterske brigade", ${ }^{85}$ pa je stoga tek nakon rata njihov nastanak ocjenjivan kao zametak nove revolucionarne vojske i oružane sile partije. ${ }^{86}$

Proces stvaranja "narodne vlasti” - od osnivanja NOO-a do AVNOJ-a i NKOJ-a - Tito je najdetaljnije opisao u izlaganju na Drugom zasjedanju AVNOJ-a te u člancima Značaj odluka AVNOJ-a za daljnji razvoj naše borbe i Borba naroda porobljene Jugoslavije. ${ }^{87} \mathrm{Za}$ razliku, Titov govor na Prvom zasjedanju AVNOJ-a ${ }^{88}$ bio je ispražnjen od pravog sadržaja jer je nakon upozorenja iz Moskve da ne čini ništa što bi štetilo sovjetskim odnosnima s Anglo-Amerikancima tada odustao od ideje o stvaranju nacionalnog komiteta kao protuteže izbjegličkoj vladi, a AVNOJ je osnovan kao političko tijelo s neodređenim statusom. ${ }^{89} \mathrm{Za}$ nimljive su one razlike u Titovim radovima koje su ovisile o adresatima kojima su pojedini tekstovi bili namijenjeni: dok je u izlaganju na Drugom zasjedanju AVNOJ-a ponajprije isticao kako su u AVNOJ-u zastupljeni „svi narodi Jugoslavije” i „svi slojevi društva”, ${ }^{90}$ u članku Borba naroda porobljene Jugoslavije pisanom za inozemnu publiku opisivao je AVNOJ kao tijelo koje ima „općepartijski karakter". ${ }^{11} \mathrm{Na}$ sličan je način Tito odgovarao i na pitanja inozemnih novinara u proljeće 1944., kada je pedantno nabrojio različite političke stranke koje su bile sastavni dio Osvobodilne fronte, ZAVNOH-a i narodnooslobodilačkog pokreta u Srbiji ${ }^{92}$ - takvi naglasci nisu bili uobičajeni u tekstovima namijenjenima domaćem čitateljstvu.

84 J. BROZ TITO, Borba za oslobodenje Jugoslavije, $1945 .^{2}, 65$. „Jedinstvo narodnih izroda”; 103. „Stvaranje Narodnooslobodilačke vojske Jugoslavije”; 143.-144. „Narodni oficiri i podoficiri”; 157.-158., 161.-162., 167.-169. „Razvitak narodno-oslobodilačke borbe u svjetlu međunarodnih zbivanja”; 211.-213. „Borba naroda porobljene Jugoslavije”.

85 O nazivu „proleterske brigade” vidi i Titovo objašnjenje koje je ponudio u referatu na Petom kongresu: J. BROZ TITO, Politički izvještaj CK KPJ, 56. O kasnijim tumačenjima o osnivanju Prve proleterske brigade, povezanima s uvođenjem Dana Jugoslavenske armije vidi: S. KOREN, Politika povijesti u Jugoslaviji, 419.

86 Vidi npr. T. ČUBELIĆ - M. MILOSTIĆ, Pregled historije NOB, 1952. ${ }^{1}, 106$.

87 J. BROZ TITO, Borba za oslobodenje Jugoslavije, 1945. ${ }^{2}$, 158.-159. i 166.-167. „Razvitak narodno-oslobodilačke borbe u svjetlu međunarodnih zbivanja”; 172.-179. „Značaj odluka AVNOJ-a za daljnji razvitak naše borbe i stvaranje federativne državne zajednice”; 211.-213. „Borba naroda porobljene Jugoslavije”.

88 Vidi: J. BROZ TITO, Borba za oslobodenje Jugoslavije, 1945. ${ }^{2}, 106 .-110$. "Govor na Prvom zasjedanju AVNOJ-a”.

89 V. DEDIJER, Josip Broz Tito: prilozi za biografiju, 338.-339. Također: J. PIRJEVEC, Tito in tovariši, 118.-123.; D. BILANDŽIĆ, Hrvatska moderna povijest, 145.

90 J. BROZ TITO, Borba za oslobodenje Jugoslavije, 1945. ${ }^{2}$, 166.-167. „Razvitak narodno-oslobodilačke borbe u svjetlu međunarodnih zbivanja".

${ }^{91}$ Isto, 211. „Borba naroda porobljene Jugoslavije”.

92 Isto, 180.-182. „Odgovori na deset pitanja inostranih novinara”. 
Sa stvaranjem „narodne vlasti” bio je povezan još jedan ključni aspekt: pitanje budućeg oblika (republika ili monarhija) i uređenja države (pitanje federacije). Pitanje monarhije Tito je na određeni način otvorio već u svojim ranim tekstovima, prikazujući ulogu dinastije Karađorđevića u međuratnoj Jugoslaviji kao nositelja „velikosrpske hegemonije” i „ugnjetavanja nesrpskih naroda” te tematizirajući bijeg kralja iz zemlje. U izlaganju na Drugom zasjedanju AVNOJ-a Tito je otvoreno i žestoko kritizirao i monarhiju i dinastiju, a osobito kralja Petra II. zbog njegove podrške „najsramnijem izdajniku” Draži Mihailoviću. ${ }^{93} \mathrm{U}$ nešto pomirljivijem tonu pisao je u proljeće 1944, ističući tek kako je donesena odluka kojom se kralju Petru II. zabranjuje dolazak u zemlju „dok poslije rata narodi, na slobodnim izborima, sami ne riješe pitanje monarhije i definitivnog unutrašnjeg uređenja. ${ }^{44} \mathrm{Tu}$ promjenu valja promatrati u kontekstu onodobnih nastojanja da se ostvari priznanje političkih tijela NOP-a, osobito nakon govora W. Churchilla u veljači 1944. u kojemu se britanski premijer odrekao četnika, no ne i kralja.

Socijalna dimenzija u Titovim tekstova nije bila prenaglašena, ali ipak stalno prisutna, osobito u onima gdje je ocrtavao planove za budućnost. Prvu Jugoslaviju opisao je kao zemlju „socijalnog bespravlja” i „socijalnog izrabljivanja”, 95 istovremeno ističući kako se NOB ne vodi samo za nacionalno, već i za socijalno oslobođenje. Primjerice, na Drugom zasjedanju AVNOJ-a: „Udareni su prvi temelji za izgradnju jedne nove, sretnije Jugoslavije, $s$ pravednijim uređenjem, koje (...) počiva na nacionalnoj ravnopravnosti, bratskoj slozi i socijalnoj pravednosti (označila S.K.)”. ${ }^{6}$ Parola „nema povratka na staro” često se pojavljivala u Titovim tekstovima. Iako su se njome zapravo nagoviještale promjene u jugoslavenskoj državi i društvu, u svojim ratnim tekstovima i govorima namijenjenima „širokim narodnim masama" (i saveznicima) Tito nije isticao revoluciju kao cilj. Tako je u izlaganju na Drugom zasjedanju AVNOJ-a odlučno zanijekao da se radi na „boljševizaciji zemlje”, proglasivši klevetom tvrdnje da je „naša narodno-oslobodilačka borba u Jugoslaviji čisto komunistička stvar” i „pokušaj komunista da uzmu vlast”. ${ }^{97}$ Takav će se diskurs postupno mijenjati nakon pobjede na izborima u studenom 1945. i donošenja Ustava početkom 1946. godine, dok u referatu na Petom kongresu Tito nije ustvrdio upravo suprotno.

\section{Nacionalno pitanje i federacija}

O budućem uređenju države Tito je pisao u nekoliko svojih tekstova, a to je gotovo uvijek bilo povezano s ocjenom o nacionalnom pitanju. Ponajprije se radi o raspravi Nacionalno pitanje u Jugoslaviji u svjetlosti narodnooslobodilačke borbe iz prosinca 1942. godine, u kojoj je Tito nagovijestio potrebu i obećanje federativnog uređenja države, istaknuvši načelo da „svaki narod ima pravo na samoodređenje do otcjepljenja”. ${ }^{8}$ Ovaj Titov tekst dobro pokazuje i kako je u praksi funkcionirala formula bratstva i jedinstva: opisujući međunacionalne odnose u međuratnoj Jugoslaviji, nastojao je uspostaviti ravnotežu, kako u udjelu

\footnotetext{
3 Isto, 165.-166. „Razvitak narodno-oslobodilačke borbe u svjetlu međunarodnih zbivanja”.

4 Isto, 212.-213. „Borba naroda porobljene Jugoslavije”.

5 Isto, 121. „Nacionalno pitanje u Jugoslaviji u svjetlosti narodno-oslobodilačke borbe”.

Isto, 172. „Značaj odluka AVNOJ-a za daljnji razvoj naše borbe i stvaranje federativne državne zajednice”.

Isto, 164. „Razvitak narodno-oslobodilačke borbe u svjetlu međunarodnih zbivanja”.

98 Isto, 122.-123., 129. „Nacionalno pitanje u Jugoslaviji u svjetlosti narodno-oslobodilačke borbe”.
} 
u patnji, tako i u podjeli krivnje za ta stradanja. $S$ jedne strane prikazana su korumpirana i pokvarena "gospoda” svih nacija (iako za odnos prema nacionalnom pitanju ipak najviše teretio „velikosrpsku gospodu”) - valja zapaziti kako Tito u tekstovima namijenjenih „masama” koristi izraz „gospoda”, umjesto izraza „buržoazija” ili (pogrdnije) „kapitalistička/reakcionarna klika" koji su bili sastavni dio njegovih prijeratnih, pa i ratnih, tekstova kojima se obraćao partijskom članstvu. Tako je i sporazum Cvetković-Maček opisan kao „podjela interesnih sfera između hrvatske i velikosrpske gospode", što je bila blaža varijanta Kominternine ocjene o ,sporazumu za daljnje izrabljivanje radnih masa i nacionalno ugnjetenih naroda Jugoslavije". ${ }^{9}$

Na drugu je stranu Tito u svojim tekstovima svrstao većinu pripadnika svih jugoslavenskih naroda od kojih je svaki na svoj način prikazan kao žrtva: Hrvati, Slovenci i Crnogorci bili su „potčinjeni narodi, neravnopravni državljani”, Makedonci i Albanci „porobljeni i podvrgnuti istrebljenju”, muslimani, njemačka i mađarska manjina služili su kao „moneta za potkusurivanje" i ,instrument u borbi protiv Hrvata i drugih naroda Jugoslavije”. Ideju da su Srbi, Hrvati i Slovenci plemena jednog naroda Tito je vrlo oštro ocijenio kao pokušaj „srbizacije Hrvata i Slovenaca”. ${ }^{100}$ No, Tito odmah dodaje kako srpski narod „nije imao ništa zajedničkog s takvom zločinačkom nacionalnom politikom svoje gospode”, već je i sam bio „izrabljivan i podvrgnut žandarmskoj samovolji kao i ostali narodi Jugoslavije”. ${ }^{01}$ Stoga su za Tita NOB i nacionalno pitanje u Jugoslaviji „nerazdvojivo vezani”: „riječ narodno-oslobodilačka borba (...) osim općeg jugoslavenskog smisla, ima i nacionalni smisao za svaki narod posebice”, odnosno znači i „oslobođenje Hrvata, Slovenaca, Srba, Makedonaca, Arnauta, muslimana, itd."102

Tito se tijekom rata rijetko upuštao u elaboriranje budućih odnosa u federaciji. Jedan (jedini?) takav primjer može se pronaći u članku iz ožujka 1944., gdje se založio za rješavanje „izvjesnih pitanja” koja pripadaju domeni federativnog uređenja još tijekom rata, kako bi se građanima u praksi pokazalo što znači federacija. Istovremeno se založio i za razgraničenje kompetencija središnje vlasti i federativnih jedinica: NKOJ mora nastojati da „već sada" prepusti federativnim jedinicama one poslove koji spadaju u njihovu domenu, ali istovremeno treba paziti da „rukovodeći organi federativnih jedinica ne preuzimaju na sebe kompetencije koje spadaju u dužnost Nacionalnog komiteta oslobođenja Jugoslavije". ${ }^{103} \mathrm{U}$ svojim je tekstovima apostrofirao i tijela čijim su se stvaranjem provodili u praksi „principi ravnopravnosti naroda Jugoslavije": već je na Drugom zasjedanju AVNOJ-a spomenuo je Osvobodilnu frontu i ZAVNOH, ${ }^{104}$ a u kasnijim tekstovima i ZAVNO BiH, ,vijeća za Crnu Goru, za Sandžak” te „Pokrajinski narodno-oslobodilački odbor” u Srbiji. Ovu je razliku u nazivu Tito objasnio time što je u Srbiji „zbog velikog terora okupatorskih trupa, nedićevaca i četnika Draže Mihailovića bilo nemoguće, putem najširih izbora, izabrati odgovarajući organ"105 - prikrivajući tako stvarnu slabost partizanskog pokreta u Srbiji, kao

Vidi npr. Rezoluciju Pete zemaljske konferencije u: Peta zemaljska konferencija KPJ, 227.

100 J. BROZ TITO, Borba za oslobođenje Jugoslavije, 1945.2, 129. „Nacionalno pitanje u Jugoslaviji u svjetlosti narodnooslobodilačke borbe”.

101 Isto, 121.-123.

102 Isto, 125., 127.-129.

103 Isto, 178.-179. „Značaj odluka AVNOJ-a za daljnji razvoj naše borbe i stvaranje federativne državne zajednice”.

104 J. BROZ TITO, Borba za oslobođenje Jugoslavije, 1945. 2, 159. „Razvitak oslobodilačke borbe naroda Jugoslavije u vezi sa međunarodnim događajima”.

105 Isto, „Borba naroda porobljene Jugoslavije”, 212. 
i činjenicu da su većinu Srba koji su se u to vrijeme borili u partizanskim redovima činili oni iz prečanskih krajeva. ${ }^{106}$

Pitanjem odnosa u federaciji Tito se više pozabavio neposredno nakon završetka rata, kada je o tome govorio u više navrata. Niz primjera iz tih govora pokazuje da je Tito prihvaćao postojanje različitih jugoslavenskih naroda kao činjenicu: npr., potrebu uspostave federacije objašnjavao je time što u Jugoslaviji „postoji više naroda” kojima treba omogućiti nesmetan kulturni i ekonomski razvoj, navodeći poimence Hrvate, Srbe, Slovence, Makedonce i Crnogorce, pa i muslimane u Bosni i Hercegovini. ${ }^{107}$ Jugoslavensku federaciju opisao je kao zajednicu „u kojoj bi svi narodi bili zadovoljni i gospodari na svome (...) i to tako da niko na drugog ne vrši pritisak, a da u isto vrijeme njegov razvitak i njegov progres ima pozitivan uticaj na ostale narode". ${ }^{108}$ Pozivao je i na međunacionalno pomirenje i prevladavanje prošlosti, koje se dijelom gradilo i na podsjećanju da je u netom završenom ratu svaki narod imao i svoje žrtve i svoje zločince - npr. u zagrebačkom govoru u svibnju 1945. istaknuo je da „možemo i moramo biti načisto da je ono što je bilo - oprano krvlju najboljih sinova svih naroda Jugoslavije, pa ga treba skinuti s dnevnog reda", referirajući pritom i na međuratno razdoblje i na rat. ${ }^{109}$ Istodobno, u više je govora istaknuo kako granice federalnih jedinica u Jugoslaviji „nisu granice razdvajanja, već granice spajanja”, opisivao ih kao „bijele crte na mramornom stubu” koje imaju administrativni karakter te je uz postojanje zasebnih nacija i federalnih jedinica spominjao „monolitnu Jugoslaviju” i pozivao na „naš općejugoslavenski patriotizam”. ${ }^{110} \mathrm{U}$ poslijeratnom kontekstu, Titov koncept monolitne Jugoslavije ponajprije je značio naglašavanje državnog jedinstva, a dobrim dijelom je proizlazio iz centraliziranog sistema odlučivanja unutar KPJ. Dugoročno, podrazumijevao je izgradnju monolitne socijalističke/komunističke države čije građane povezuje ista ideologija, a ne monolitne države u odnosu na nacionalno pitanje. ${ }^{11}$

\section{Saveznici i suparnici}

U Titovim se tekstovima Sovjetski Savez spominjao s posebnim pijetetom: redovito se navodio na prvom mjestu kada su se nabrajali „naši saveznici”, opisivan je kao najveća zapreka u ostvarivanju Hitlerovih ciljeva, veličale su se njegove vojne pobjede te iskazivala vjera u brzu pobjedu Crvene armije. Sovjetskim narodima i vojsci upućivali su se „plameni pozdravi”, a vođama („veliki učitelj i vođ međunarodnog proletarijata, Lenjin, i njegov vjerni učenik drug Staljin" ${ }^{112}$ ) odavala dužna počast. Tijekom rata Tito je napisao i nekoliko članaka koji su bili u potpunosti posvećeni SSSR-u, a kojima su se obilježavale godišnjice

\footnotetext{
106 Usp. J. PIRJEVEC, Tito in tovarisi, 162.-163.

107 J. BROZ TITO, Izbor iz djela, knj. 2, 192.-193. (govor na osnivačkom kongresu KP Srbije 12. 5. 1945.); ISTI, Izbor iz djela, knj. 3, 90.-91. (govor u Zagrebu 21. 5. 1945.).

108 J. BROZ TITO, Izbor iz djela, knj. 3, 92. (govor održan u Beloj Crkvi 7. 7. 1945., prigodom prve proslave Dana ustanka u Srbiji).

109 Isto, 91.

110 Vidi bilj. 106 i 107. Također: „Govor maršala Tita u Ljubljani 27. svibnja 1945”, Biblioteka „Slobodna Dalmacija”, Split 1945., 16.

111 Usp. Olivera MILOSAVLJEVIĆ, „Titov Jugoslaven - nacionalni ili državni identitet?”, Dijalog povjesničara-istoričara, knj. 7, Zagreb 2003., 175.-192.; D. BILANDŽIĆ, Hrvatska moderna povijest, 228.-229.

112 J. BROZ TITO, Borba za oslobođenje Jugoslavije, 1945. 2, 35. „Godišnjica Crvene armije”.
} 
Oktobarske revolucije i osnivanja Crvene armije ili prekretnice u ratu poput oslobađanja Lenjingrada. ${ }^{113} \mathrm{Za}$ razliku, njegove ocijene o zapadnim saveznicima bile su podložne mijenama. U jesen 1940. Tito je u svoj politički referat na Petoj zemaljskoj konferenciji ugradio Kominterninu ocjenu o karakteru Drugog svjetskog rata kao drugog imperijalističkog rata, opisavši ga kao rat koji vodi „kapitalistički svijet” - engleski i francuski imperijalisti protiv njemačkih i talijanskih imperijalista - zbog nove podjele svijeta i porobljavanja malih država i naroda. Kao kontrast, Tito je prikazao zamišljenu sovjetsku „dosljednu politiku mira i zaštitnika malih naroda” te „sreću i blagostanje dvjestomilijunske bratske zajednice naroda". ${ }^{114} \mathrm{Na}$ sličan je način pisao i u članku o savjetovanju KPJ održanom u svibnju 1941. u Zagrebu, gdje je sve sukobljene strane strpao u isti (imperijalistički) koš, zatraživši od partijskog članstva da „treba neumorno raskrinkavati razne agente imperijalističkih sila, kako one koji rade za osovinske osvajače, tako i one koji rade za Engleze i za povratak starog stanja koje je i dovelo do današnje katastrofe" (mogući razlog da taj tekst nije uvršten u prve zbirke Titovih radova?). ${ }^{15}$

No, kako su se mijenjale ratne prilike te razvrgavali i sklapali vojni i politički savezi, tako su se mijenjale i Titove ocjene. U svojim je kasnijim tekstovima ublažio ocjene o imperijalističkom karakteru rata, ${ }^{116}$ no nikad nije prestao gledati na zapadne saveznike kao na ideološke „druge”. Još do sredine 1942. Tito je povremeno i dalje spominjao kako „u Engleskoj i u Americi ima ne mali broj reakcionarnih klika, čije su simpatije još uvijek na strani Hitlera, kao udarne pesnice međunarodne reakcije". ${ }^{117}$ Ovakve su žaoke nestale u kasnijim tekstovima: u njima je Tito sve saveznike karakterizirao pozitivno te priznavao materijalnu i političku podršku koju su zapadni saveznici upućivali partizanima, ali je o „Engleskoj i Americi" pisao bez onog entuzijazma koji je bio rezerviran samo za SSSR.

Prikazujući sukobljene strane u Jugoslaviji, Tito je jasno i nedvosmisleno dijelio „zdrave narodne snage” od „okupatora i njihovih domaćih pomagača” koji su prikazani kao ultimativno zlo. Prve je činila većina pripadnika svih jugoslavenskih naroda, „radnika, seljaka i poštene inteligencije" 118 - valja zapaziti kako je u navedenoj trijadi Tito jedino za inteligenciju koristi izraz koji istovremeno dijeli i isključuje one „druge” (postavlja se pitanje koliko je ta kategorija za Tita bila promjenjiva, ovisno o vremenu i okolnostima). Iako je u Titovim tekstovima glavni negativac bio „okupator”, ponajprije onaj njemački i talijanski, ipak je glavni fokus bio na „narodnim neprijateljima” i „narodnim izdajicama”. Od početka do kraja rata, u Titovim se tekstovima kao suradnici okupatora, „izdajice” i „petokolonaši” navode Milan Nedić i njegova „marionetska vlada”, Dimitrije Ljotić, Kosta Pećanac u Srbiji te Ante Pavelić i ustaše u Hrvatskoj. U najranijim tekstovima Tito je poimence apostrofirao još i Milana Aćimovića u Srbiji, te Andriju Artukovića i Milu Budaka u NDH. ${ }^{119}$ Leon Rupnik i slovenski domobrani nisu bili u fokusu Titova interesa sve do pred kraj rata: prvi

\footnotetext{
113 Isto, 29.-32. „Godišnjica Crvene armije”; 82.-88. ”Dnevna zapovijest za 7 novembar 1942”; 91.-98. "Četvrt vijeka od Velikog oktobra"; 139.-142. "Lenjingrad je oslobođen".

114 Peta zemaljska konferencija KPJ, 3.-5.

115 J. BROZ TITO, Izbor iz djela, knj. 2, 137.-147. „Savjetovanje Komunističke partije Jugoslavije”.

116 Npr. J. BROZ TITO, Borba za oslobođenje Jugoslavije, 1945.2, 63. „Nacionalno pitanje u svjetlosti narodnooslobodilačke borbe".

117 Isto, 39., 40.-41. „Godišnjica Crvene armije”; 43. „Komunistička partija i ko su sve saveznici okupatora?”.

118 Isto, npr. stranica 49. „Komunistička partija i ko su sve saveznici okupatora?”.

119 Isto, 16. „Još jedna izdajnička marionetska vlada”; 19 „Teror fašističkih bandita”.
} 
puta ih je spomenuo tek u proljeće 1944. godine, u istom kontekstu i na isti način kao i ostale „izdajnike naroda”. ${ }^{120}$

U ranim tekstovima nastalima u kasno ljeto i ranu jesen 1941. fokus je ponajprije bio na situaciji u Srbiji. Prikazujući svoje ratne suparnike Tito nije birao riječi: npr. Nedić je opisan kao „prljavi starac”, „odvratni srpski izdajnik”, „njemački špijun” i „hulja”, a njegova vlada kao „jedno malo šugavo nedonošče” i „najnovije čedo ludog Hitlera”. U svojim je ranijim tekstovima Tito tretirao Nedića, Ljotića, Pećanca kao srpski pandan ustašama, nazivajući ih na više mjesta „srpskim Pavelićima” i „srpskim ustašama”. ${ }^{121}$ Posebice je isticao kako oni čine Srbima u Srbiji isto ono što im u Hrvatskoj čine ustaše, ${ }^{122}$ pritom ipak radeći jasnu brojčanu distinkciju: ustaše su odgovorni za ubojstva „stotine hiljada Srba: žena, djece i staraca”, dok je od ruke „srpskih izroda” poginulo „hiljade srpskih sinova i kćeri”. ${ }^{123}$ Iako ustaše nisu bile u fokusu Titovih ranih tekstova, atribucije koje im je dodijelio nisu bile ništa blaže: nazivao ih je „novopečenim Gotima” i „krvavom ruljom pljačkaških bandita”, a Pavelića „ogavnim hrvatskim izdajnikom”, „zločincem” i „plaćenim njemačkim i talijanskim agentom". U prikazu ustaških zlodjela Tito je ponajviše isticao ubijanja Srba, povremeno i ubijanja Hrvata, dok je pokolje Zidova spomenuo samo jednom. ${ }^{124}$

U članku Komunistička partija i ko su sve saveznici okupatora (travanj 1942.) Tito se po prvi puta tijekom rata žestoko obrušio i na vodstva građanskih stranka, ponajprije na srpsku i hrvatsku „reakcionarnu gospodu” („slovenačke reakcionare na čelu sa Korošcem, Natlačenom, Krekom i drugima" Tito je u svojim ratnim tekstovima spomenuo tek jednom $\left.^{125}\right)$. Kritici je izložio „protagoniste (...) politike uprezanja Jugoslavije u osovinska fašistička kola” Milana Stojadinovića i Dragišu Cvetkovića, kojima je nekoliko mjeseci kasnije pribrojio i Bogoljuba Jevtića. Ovaj je članak, uz nešto kasniji tekst Nacionalno pitanje u Jugoslaviji u svjetlosti narodno-oslobodilačke borbe, ujedno predstavljao i najžešći Titov napad na „reakcionarno vodstvo” HSS-a i Vladka Mačeka, koje je optužio da su svojim „špekulantskim držanjem” i odbijanjem suradnje s partizanima „glavna smetnja za opći narodni ustanak protiv okupatora u Hrvatskoj" i razlog zašto "hrvatski narod nije do sada stupio masovno, po primjeru srpskog, crnogorskog, slovenskog naroda, u oružanu borbu protiv okupatora". ${ }^{126}$ Ipak, ukupan je dojam da se Tito u svojim ratnim tekstovima znatno manje bavio Mačekom i HSS-om nego primjerice Nedićem, a osobito Mihailovićem ili izbjegličkom vladom, već je tu zadaću prepustio KP Hrvatske i njezinom tisku, prema smjernicama koje su dobivali od Centralnog komiteta KPJ. ${ }^{127}$

${ }_{120}$ Isto, 215. „Borba naroda porobljene Jugoslavije”. Također: ISTI, Izbor iz djela, knj. 3, 89. (govor u Zagrebu 21. 5. 1945.); ISTI, Izbor iz djela, knj. 2, 205.-206. (govor na Prvom kongresu NFJ, 7. 8. 1945.); ISTI, „U čemu je specifičnost oslobodilačke borbe i revolucionarnog preobražaja Jugoslavije”, Komunist, 1/1946., 1.-9.

121 Isto, 14.-16. „Još jedna izdajnička marionetska vlada”; 17.-19., 21. „Teror fašističkih bandita”, 46. „Komunistička partija i ko su sve saveznici okupatora?".

122 Isto, 50.-51. „Komunistička partija i ko su sve saveznici okupatora?”.

123 Isto, 17.-19. „Teror fašističkih bandita”.

124 Isto, 15, 17. „Još jedna marionetska vlada”; 18. „Teror fašističkih bandita”, 31. „Komunistička partija Jugoslavije u današnjoj narodno-oslobodilačkoj borbi”; 31. „Komunistička partija Jugoslavije u današnjoj narodno-oslobodilačkoj borbi; 51. „Komunistička partija i ko su sve saveznici okupatora”, 63., 65. „Jedinstvo narodnih izroda”.

125 Isto, 125. „Nacionalno pitanje u svjetlosti narodno-oslobodilačke borbe”.

126 Isto, 43.-52. „Komunistička partija i ko su sve saveznici okupatora?”; 125. „Nacionalno pitanje u svjetlosti narodnooslobodilačke borbe”.

127 Više o odnosu HSS-a i NOP-a vidi u: Fikreta BUTIĆ-JELIĆ, Hrvatska seljačka stranka, Zagreb 1983., 127.-226.; Ivan JELIĆ, Komunistička partija Hrvatske 1937 - 1945, drugi svezak, Zagreb 1981., 231.-254.; Ljubo BOBAN, Kontroverze iz povijesti Jugoslavije 2, Zagreb 1989., 254.-261.; Jozo TOMASEVICH, Rat i revolucija u Jugoslaiji 1941-1945. Okupacija i kolaboracija, Zagreb 404.-410. 
Odnos prema Draži Mihailoviću i njegovim četnicima bio je diferenciraniji i kompleksniji i mijenjao se postupno, a s tim je tijesno bio povezan i stav prema kralju i jugoslavenskoj vladi u izbjeglištvu. U ranim tekstovima nastalima u kasno ljeto i ranu jesen 1941. četnici Draže Mihailovića još nisu ni protivnici ni negativci - štoviše, Tito je tada pisao o „poštenim četnicima”, kako bi ih razlikovao od četnika Koste Pećanca, ${ }^{128}$ ili o raznim pljačkaškim bandama koje „pod imenom četnika pljačkaju i ubijaju nedužno hrvatsko i muslimansko stanovništvo". ${ }^{129} \mathrm{Za}$ promjenu stava presudni su bili tekstovi objavljeni u proljeće 1942. godine. Tito je prvi puta ubrojio Mihailovićeve četnike među „domaće sluge okupatora" u članku Godišnjica Crvene armije objavljenom u Foči u veljači 1942., no tada još nije detaljnije elaborirao svoje tvrdnje. ${ }^{130}$ To je učinio dva mjeseca kasnije, u već više puta spominjanom članku Komunistička partija $i$ ko su sve saveznici okupatora, gdje je ustvrdio kako „Dražina vojska” u tom trenutku više ne postoji kao zasebna vojna formacija, već se „slila sa ostalim četničkim bandama” s kojima napada partizanske odrede te „ubija i pali kuće nedužnih stanovnika Bosne i Srbije pod imenom Nedića"."131

Ipak, u proljeće 1942. Tito je još uvijek bio znatno oštriji prema Nediću i Pećancu nego prema Draži Mihailoviću, pa je, primjerice, pisao da „narod s pravom zove Nedića, Pećanca i ostale četnike - srpskim ustašama” ili da su „Nedić, Pećanac i mnogi drugi postali (...) srpski Pavelići”. ${ }^{132}$ Dok u navedenim primjerima Mihailovića još uvijek valja tražiti među „ostalima” i „drugima”, u tekstovima nastalima u ljeto i jesen 1942. Tito je sve više izjednačavao upravo Mihailovićeve četnike s ustašama. Tako je u kolovozu 1942. pisao o „izdaji četnika sviju dlaka”, ${ }^{133}$ da bi nešto kasnije, nabrajajući protiv koga se sve bori NOVJ (,protiv njemačkih, italijanskih, mađarskih, bugarskih okupatora i njihovih slugu, Pavelićevih ustaša, Nedićevih i Pećančevih četnika, kao i protiv četnika Draže Mihailovića”), naglasio kako između „svih tih okupatorskih slugu” nema nikakvih razlika. ${ }^{134}$ Konačno, krajem 1942. izjednačio je Pavelića, Nedića i Mihailovića čak i odabirom identičnih riječi i izraza:

Što predstavlja danas Pavelić i njegova ustaška banda u Hrvatskoj? Ništa drugo do obične agente u okupiranoj i porobljenoj Hrvatskoj. Što predstavlja danas Nedić i kompanija u Srbiji? Ništa drugo do agenta okupatora u okupiranoj i porobljenoj Srbiji. Što predstavlja danas Draža Mihailović i njegovi četnici u Jugoslaviji? Ništa drugo do agente i saveznike okupatora u borbi protiv naroda. Ali svi ti banditi služe ne samo kao agenti, već kao svirepi krvnici u službi okupatora, pomoću kojih on nemilosrdno istrebljuje naše narode (...). ${ }^{135}$

Ovakvo verbalno izjednačavanje ustaša i četnika u kasnijim je Titovim tekstovima i govorima postalo redovita pojava. To je dijelom bio rezultat Titova fokusa na one snage koje je smatrao ključnim protivnicima i suparnicima u borbi za vlast, a u prvim poslijeratnim mjesecima i izraz potrebe da se poražene protivnike ili potencijalne suparnike u borbi za vlast što više dezavuira. Tako u govoru na osnivačkom kongresu KP Srbije (Beograd, 12.

\footnotetext{
128 J. BROZ TITO, Borba za oslobođenje Jugoslavije, 1945. ${ }^{2}, 16$. „Još jedna izdajnička marionetska vlada”.

129 Isto, 22. „Savjetovanje predstavnika štabova i komandanata narodno-oslobodilačkih partizanskih odreda Jugoslavije”.

130 Isto, 41. „Godišnjica Crvene armije”.

131 Isto, 47., 48., 49.-50., 51. „Komunistička partija i ko su sve saveznici okupatora”.

132 Isto, 46., 50.

133 Isto, 75. „Godišnjica narodno-oslobodilačke borbe u Jugoslaviji”.

134 Isto, 77.-81. „Međunarodni značaj narodno-oslobodilačke borbe u Jugoslaviji i zamaskirani izdajnici”.

135 Isto, 127. „Nacionalno pitanje u Jugoslaviji u svjetlosti narodno-oslobodilačke borbe”.
} 
svibnja 1945.) Tito nije pravio baš nikakvu razliku između ustaša i četnika: „Ako su Hrvati imali ustaše, onda su Srbi imali četnike. U čemu je razlika između jednih i drugih?”. ${ }^{136}$ Dijelom je to izjednačavanje bilo i posljedica formule bratstva i jedinstva prema kojoj je svaki jugoslavenski narod imao svoje heroje, žrtve i „narodne neprijatelje i izdajice”. Na to ukazuje sljedeći primjer iz članka Borba naroda porobljene Jugoslavije, pri čemu valja zapaziti da Tito, iako svodi u istu ravan ustaše i četnike, ipak ne izjednačava i domete zločina koje su počinile dvije strane:

Ustaše su, pod rukovodstvom Nijemaca, ubijali stotine hiljada Srba, četnici Draže Mihailovića, pod rukovodstvom Italijana i Nijemaca, ubijali su desetine hiljada muslimana i Hrvata. (...) Naša parola bila je bratstvo i jedinstvo naroda Jugoslavije. Mi smo činili sve napore, dokazujući ogorčenom srpskom življu i zavedenim četnicima da svi Hrvati nisu zlikovci, da svi muslimani nisu zlikovci, već samo jedan mali dio u ustaškim odredima, koji pod vodstvom Nijemaca vrši zlodjela. Dokazivali smo svim mogućim načinima ojađenom muslimanskom i hrvatskom življu da Srbi nisu zlikovci, nego da zvjerstva vrši samo šaka četnika Mihailovića, Pećanca i Nedića. ${ }^{137}$

Još jedna važna tema u Titovim prikazima partizansko-četničkih sukoba bili su i događaji u Srbiji u jesen 1941. godine. O tome je Tito počeo pisati od ljeta 1942. godine, kada je prvi puta izravno optužio Mihailovićeve četnike da su kod Užica napali partizane s leđa i tako doprinijeli slomu ustanka. ${ }^{138}$ Najopširniji prikaz razvoja partizansko-četničkih odnosa Tito je donio u tekstu Borba naroda porobljene Jugoslavije (1944.), gdje je vrlo detaljno prikazao prve ratne mjesece, od pregovora i pokušaja suradnje, do prvih sukoba za koje krivicu pripisuje četnicima. U opis tih događaja Tito je unio i osobnu notu: opisao je pregovore u prvom licu i iznosio detalje o svojim razgovorima s Dražom Mihailovićem koje ne iznosi ni u jednom drugom (ratnom) tekstu. ${ }^{139} \mathrm{~S}$ tim je bilo povezano i pitanje o tome „tko je prvi otišao u šumu” i zašto, o čemu je Tito pisao u više navrata i u raznim varijantama. Primjerice:

Neki u inostranstvu još i danas govore da je Draža Mihailović prvi otišao u šumu. Da, Draža Mihailović je prvi pobjegao u šumu, a mi smo ostali u gradovima, u kojima je bila većina stanovništva i njemačkih snaga. Tu smo mi stvarali planove za buduće operacije. Razlika je među nama bila u tome što je on prvi otišao u šumu da se sakrije. A mi smo išli u šumu s stvorenim planom, $s$ riješenošću da odande počnemo operacije. ${ }^{140}$

Opisujući te i druge „teške borbe” s četnicima od Užica do bitke na Neretvi, Tito je posebice nastojao raskrinkati četničku kolaboraciju s Nijemcima, Talijanima i ustašama. To je bilo povezano i s eskalacijom kritika na račun jugoslavenske vlade u izbjeglištvu. U svojim ranim tekstovima, Tito je kraljevsku vladu spominjao rijetko ili uopće nije spominjao, a naročito ne u negativnom svjetlu. Čak i u tekstu Komunistička partija i ko su sve saveznici okupatora, gdje je oštro napao četnike, bio je vrlo suzdržan u kritikama na račun vlade, ${ }^{141}$

\footnotetext{
136 J. BROZ TITO, Izbor iz djela, knj. 2, 198.

137 ISTI, Borba za oslobodenje Jugoslavije, $1945 .^{2}, 213$. „Borba naroda porobljene Jugoslavije”.

138 Isto, 65. "Jedinstvo narodnih izroda”.

139 Isto, 191.-199. „Borba naroda porobljene Jugoslavije”.

140 J. BROZ TITO, Izbor iz djela, knj. 2, 295. "Jugoslovenska armija i bivši oficiri-zarobljenici”, govor na zboru oficira bivše Jugoslavenske vojske koji su se vratili iz ratnog zarobljeništva, održan u Zemunu 16. 10. 1945.

${ }_{141}$ ISTI, Borba za oslobođenje Jugoslavije, 1945. ${ }^{2}, 43$. „Komunistička partija i ko su sve saveznici okupatora”.
} 
pritom vjerojatno vodeći računa o međunarodnim obvezama SSSR-a, koji je vladu priznavao. No, to se promijenilo već od ljeta 1942. kada je Tito u svojim tekstovima počeo žestoko napadati vladu u Londonu. To je koincidiralo $s$ razdobljem kada je putem raznih kanala uspio plasirati u inozemstvo svoju priču o ratu u Jugoslaviji, osobito na zapad gdje se dugo vremena smatralo da pokret otpora nose četnici Draže Mihailovića. ${ }^{142}$

Sudeći po intenzitetu i učestalosti kojom je pisao o toj „nečuvenoj prevari čitave poštene svjetske javnosti", ${ }^{143}$ Tita je osobito jedilo to što su se njegovi ratni pothvati pripisivali Mihailoviću. Već je u ljeto 1942. pisao kako je izbjeglička vlada proturala u međunarodnu javnost lažne vijesti i „stvarala o Draži Mihailoviću legendu kao o nekom heroju i genijalnom vojskovođi” ${ }^{44}$ ili kako je „naše lovorike brao Draža Mihalović, koji je postao u inostranoj štampi Robin Hud, a naša partizanska i dobrovoljačka vojska, njeni borci - to su bili neznani junaci." 145 U tekstovima objavljenima u jesen 1942. Tito je počeo koristiti izraz izdajnička vlada, a potom je u nekoliko navrata ponovio kako partizani tu vladu ne priznaju jer ona „preko svog ministra Draže Mihailovića” izravno pomaže okupatoru. ${ }^{146}$ To je bilo nakon što se sovjetska vlada u ljeto 1942. već odlučila žigosati Dražu kao izdajicu, pa je Tito osjećao da ima odriješene ruke. ${ }^{147} \mathrm{U}$ kasnijim tekstovima fokusirao se na poraz četnika u bitki na Neretvi koji je prikazao kao vrhunac četničke kolaboracije i ujedno bitku u kojoj su partizanske jedinice „zadale konačan udarac i likvidirale njegove [Mihailovićeve] četnike kao neku ozbiljnu vojničku snagu". Tito je naglašavao i kako su nakon poraza četnika na Neretvi u ruke partizana dospjeli mnogobrojni dokumenti koji su raskrinkali „pakleni plan” za uništenje NOVJ. Nakon toga „izdajnička izbjeglička londonska vlada” više „nije mogla zataškavati [činjenice] pred svjetskom javnošću”, pa je „prevara bila konačno otkrivena". ${ }^{148}$

\section{Referat na Petom kongresu KPJ}

Ovi su Titovi tekstovi već tijekom rata počeli intenzivno umnažati te su izvršili snažan utjecaj na oblikovanje pripovijesti o ratu. U prvim poslijeratnim godinama, izdvaja se članak $U$ čemu je specifičnost oslobodilačke borbe i revolucionarnog preobražaja nove Jugoslavije koji je objavljen u prvom broju Komunista iz listopada 1946. godine, sada već u novim okolnostima nakon izborne pobjede i donošenja Ustava. U njemu je Tito u nekoliko točaka sumirao „specifičnosti oslobodilačke borbe Jugoslavije”, ali i nagovijestio značajne društvene promjene. Stoga je i NOB-u pripisano novo značenje: Tito je na nekoliko mjesta istaknuo je da su se tijekom rata stvarali država i društvo „novog tipa” (koje, doduše, ne imenuje),

$\overline{142}$ Isto, 77.-81. „Međunarodni značaj narodno-oslobodilačke borbe u Jugoslaviji i zamaskirani izdajnici”. Vidi također: J. PIRJEVEC, Tito in tovariši, 119.

${ }_{143}$ Ovu je frazu upotrijebio u izlaganju na Drugom zasjedanju AVNOJ-a. Vidi: J. BROZ TITO, Borba za oslobođenje Jugoslavije, $1945 .^{2}, 161$.

144 Isto, 78.-79. „Međunarodni značaj narodno-oslobodilačke borbe u Jugoslaviji i zamaskirani izdajnici”.

145 Isto, 97.-98. „Govor povodom predaje zastave Prvoj proleterskoj brigade”; 161. „Razvitak oslobodilačke borbe u vezi s međunarodnim događajima”; 214.-215. „Borba naroda porobljene Jugoslavije”.

146 Isto, 85. „Govor povodom predaje zastave Drugoj proleterskoj brigadi”; 97. „Govor povodom predaje zastave Prvoj proleterskoj brigadi”; 161. „Razvitak oslobodilačke borbe u vezi s međunarodnim događajima”.

147 J. PIRJEVEC, Tito in tovariši, 118.-119.

148 J. BROZ TITO, Borba za oslobođenje Jugoslavije, 1945.², 161. „Razvitak oslobodilačke borbe u vezi s međunarodnim događajima". 


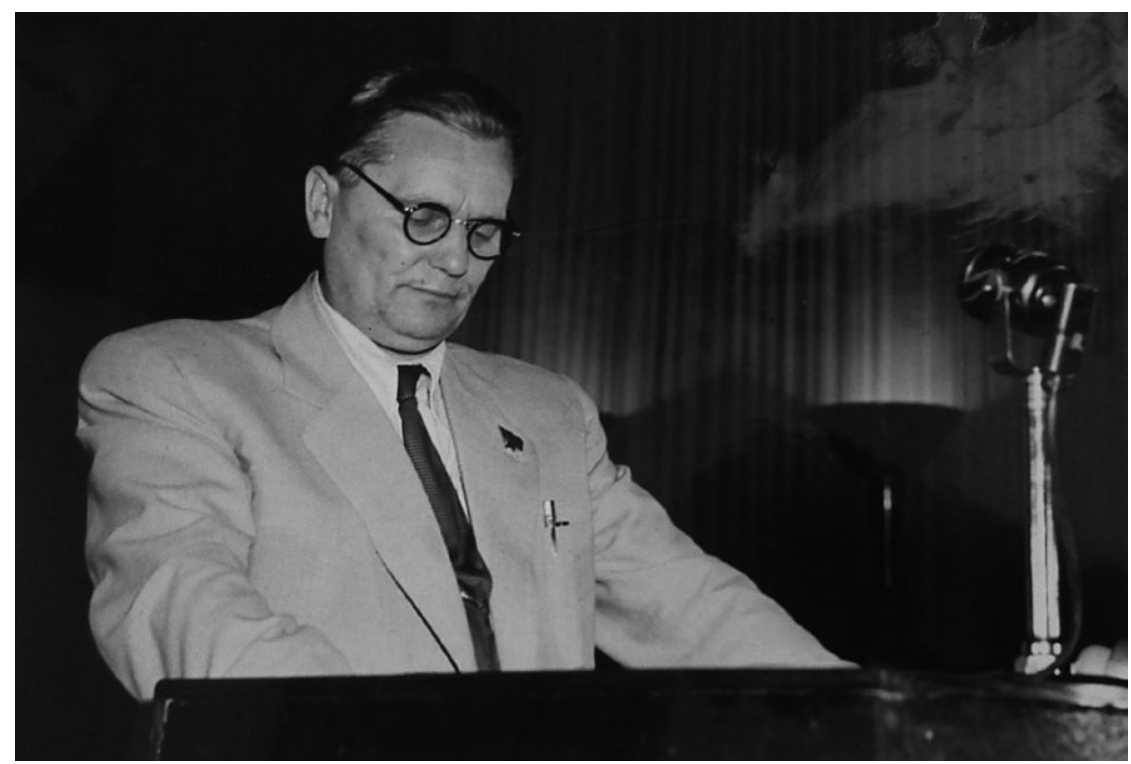

Slika 3. Josip Broz Tito čita referat na Petom kongresu KPJ

označivši to „revolucionarnim putem koji još nije dovršen”. Tu je tvrdnju u potpunosti razradio u vrijeme sukoba sa SSSR-om. ${ }^{149}$

Kao i u mnogim drugim sferama političkog i javnog života, sukob sa SSSR-om utjecao je i na promjene narativa o NOB-u. U pismima koja su Staljin i Molotov uputili Politbirou CK KPJ, a osobito u pismu od 4. svibnja 1948. godine, izneseno je i njihovo viđenje o završnim mjesecima rata na tlu Jugoslavije. Staljin i Molotov stavili su Jugoslaviju u istu ravan s ostalim zemljama narodne demokracije jer je u njihovoj interpretaciji SSSR pritekao u pomoć jugoslavenskim partizanima u trenutku kad je NOP nakon desanta na Drvar bio razbijen, a zasluga za oslobađanje zemlje i dolazak KPJ na vlast pripisana je intervenciji Crvene armije:

(...) posle razbijanja štaba jugoslovenskih partizana od strane nemačkih padobranaca, u momentu kada je narodno-oslobodilački pokret u Jugoslaviji preživljavao tešku krizu, Sovjetska armija pritekla [je] u pomoć jugoslovenskom narodu, razbila nemačke okupatore, oslobodila Beograd i tako stvorila uslove neophodne za dolazak komunističke partije na vlast. Nažalost, Sovjetska armija nije ukazala i nije mogla ukazati takvu pomoć francuskoj i italijanskoj kompartiji. Kad bi drugovi Tito i Kardelj uzeli u obzir ovu okolnost kao neosporiv fakat, oni bi manje galamili o svojim zaslugama i držali bi se pristojnije, skromnije $(. ..){ }^{150}$

Ovakvo je tumačenje, naravno, bilo u potpunoj suprotnosti sa slikom o ratu koja su još od vremena rata gradili jugoslavenski komunisti, ponajviše baš u Titovim tekstovima. Odgovor na te kvalifikacije, kao i na druge optužbe iz pisama i Rezolucije Informbiroa, iznesen je ponajprije u političkom referatu Josipa Broza Tita na Petom kongresu KPJ krajem srp-

\footnotetext{
149 J. BROZ TITO, „U čemu je specifičnost oslobodilačke borbe i revolucionarnog preobražaja Jugoslavije”, Komunist, 1/1946. 1.-9.

150 Branko PETRANOVIĆ - Momčilo ZEČEVIĆ, Jugoslavija 1918 - 1984. Zbirka dokumenata, Beograd 1985., 759.
} 
nja 1948. godine. ${ }^{151}$ Svojim je odabirom događaja, ocjena i argumenata trebao opovrgnuti iznesene optužbe i poslužiti kao potvrda ispravnosti politike vodstva partije u trenutku kada je ono bilo izloženo oštrim kritikama SSSR-a i ostalih zemalja „narodne demokracije”. No, Titovo izlaganje bilo je više od običnog referata: bio je to historijat KPJ koji je započinjao s pojavom radničkog pokreta, a potom donosio sustavan pregled povijesti KPJ od njezina osnivanja do 1948. godine. Upravo je ratnom razdoblju pripalo središnje mjesto: NOB je prikazan kao zvjezdani trenutak Partije i vrhunac borbe jugoslavenskih komunista za revolucionarni preobražaj društva. Tom je dijelu svojeg izvještaja Tito posvetio najviše prostora (48 od ukupno 92 stranice) i obilno ga potkrijepio brojnim dokumentima koji su trebali ponuditi potporu njegovima argumentima (citira tekstove iz partizanskog tiska, osobito Biltena Glavnog/Vrhovnog štaba, naredbe Vrhovnog štaba, agenciju TASS, ali i „neprijateljske izvore", primjerice tajne izvještaje Ministarstva hrvatskog domobranstva, pa i njemački tisak). ${ }^{152}$

Tito je u referatu detaljnije opisao i razdoblje od ljeta 1944. do kraja rata koje nije prikazao u svojim ratnim tekstovima. Umanjio je značaj desanta na Drvar, ocijenivši ga kao „ustvari samo očajnički akt osvete i pokušaj likvidacije glavnih vođa ustanka,"153 dok je odlazak na Vis prikazao kao odluku Vrhovnog štaba. ${ }^{154}$ Detaljnije je razradio „izvjesne greške” koje su tijekom rata počinile pojedine partijske organizacije (npr. tijekom ustanka u Crnoj Gori, slučaj Šatorova u Makedoniji, „oportunizam” partijskih organizacija u Sloveniji u Hrvatskoj), što mu je ujedno poslužilo i da otvori slučaj Andrije Hebranga. ${ }^{155}$ Lista ratnih neprijatelja i „slugu okupatora” proširio je, uključivši u nju srpsku, hrvatsku i slovensku „buržoaziju” u cjelini, kao i „ogromnu većinu katoličkih popova”, poimence apostrofirajući zagrebačkog nadbiskupa Alojzija Stepinca, vrhbosanskog biskupa Ivana Šarića i i ljubljanskog biskupa Gregorija Rožmana. ${ }^{156}$ Konačno, u posljednjem dijelu referata Tito je opisao rad na stvaranju FNRJ, prikaz koji započinje s 1944. i sporazumima sa Šubašićem, nastavlja se detaljnim prikazom normativnih akata, mjera i postupaka koji su bili temelj socijalističkog preobražaja države i društva, a završava s odbacivanjem optužbe iznesene u rezoluciji Informbiroa koje naziva „strašnom zabludom”. 157

U dijelu Titova referata posvećenom ratnom razdoblju postoji nekoliko značajnijih razlika u odnosu na ranije tekstove koje se mogu čitati kao odgovor na kvalifikacije iznesene u pismima Staljina i Molotova. Kao prvo, to je bitno detaljniji opis i znatno naglašenija uloga KPJ, osobito Centralnog komiteta i njegova Politbiroa, u organiziranju ustanka, kao i u kasnijem tijeku oružane borbe. Upravo je pripremi i prvim mjesecima ustanka posvećena iznimno velika pozornost, pri čemu se naglašavaju aktivnosti prije napada na SSSR,

151 Titov referat na Petom kongresu tiskan je u raznim verzijama. Svi citati iz ovog referata navode se prema sljedećoj publikaciji: Josip BROZ TITO, Politički izvještaj Centralnog komiteta Komunističke partije Jugoslavije: referat održan na Vkongresu KPJ, Beograd 1945.

152 Prema Lj. Dimiću, nekoliko mjeseci ranije u CK KPJ poslani su neki dokumenti iz vojnog arhiva koji su trebali biti upotrijebljeni za pisanje referata generalnog sekretara. Đorđe STANKOVIĆ - Ljubodrag DIMIĆ, Istoriografija pod nadzorom. Prilozi istoriji istoriografije I, Beograd 1996., 290.

153 J. BROZ TITO, Politički izvještaj CK KPJ, 67.

${ }_{154}$ Isto, 68.

155 Isto, 73.-74.

156 Isto, 76.-77.

157 Isto, 76.-93. Valja napomenuti da je o sporazumima sa Šubašićem Tito govorio i prije, npr. u ekspozeu na Trećem zasjedanju AVNOJ-a. Vidi npr.: J. BROZ TITO, Opštenarodna odbrana i društvena samozaštita, 287.-292. 


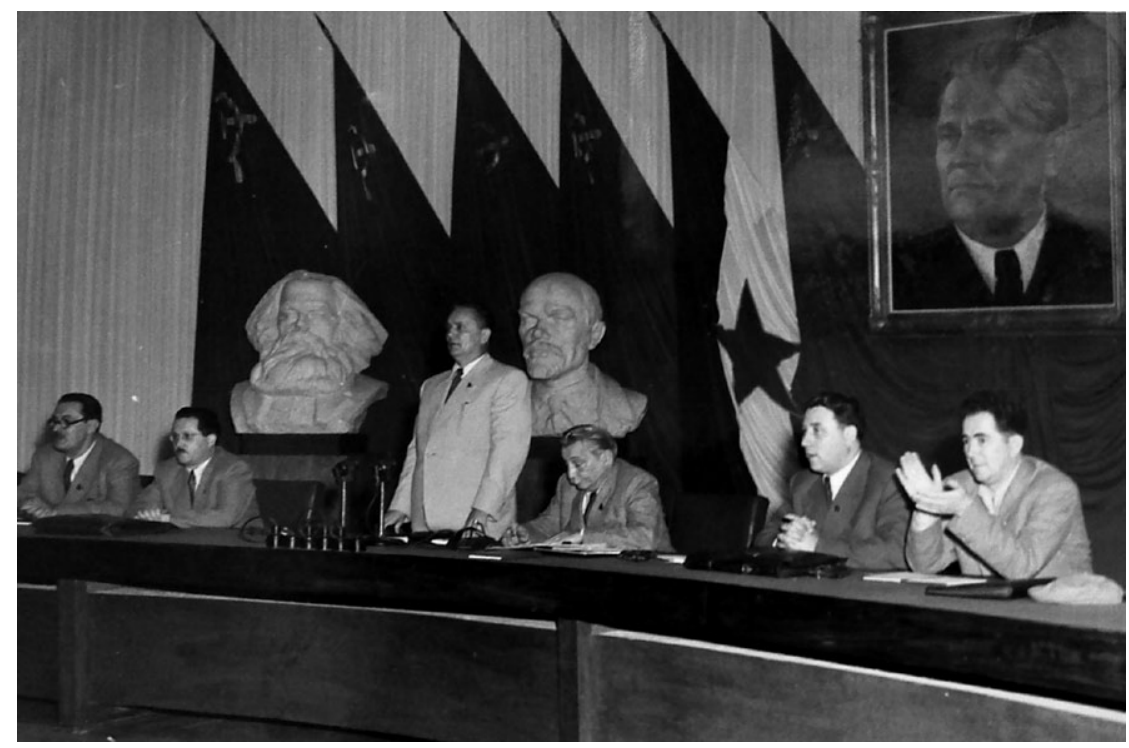

Slika 4. Peti kongres KPJ 1948. S desna na lijevo: Milovan Đilas, Aleksandar Ranković, Moša Pijade, Josip Broz Tito, Edvard Kardelj, Franc Leskošek Luka

odnosno ističe se kako su narodi Jugoslavije stupili u borbu i prije poziva Kominterne od 22. lipnja $1941 .{ }^{158}$ Zašto je tomu tako, Tito je u referatu izravno i objasnio:

Zašto sam se ja zadržao malo više na događajima prvih mjeseci narodnog ustanka, to jest do polovice septembra mjeseca 1941 godine? Zadržao sam se zbog toga, da bih jasnije podvukao da je narodni ustanak u Jugoslaviji od samog početka imao organizovani, planski karakter, da bih podvukao da je taj ustanak organizirala i vodila samo naša Komunistička partija Jugoslavije, da bih podvukao da je taj ustanak imao za cilj, osim borbe za vlastito oslobođenje, i pomoć herojskoj borbi naroda Sovjetskog Saveza, koje je u to vrijeme potpuno sam primio sav teret borbe na svoja leđa. Drugim riječima, da bih odgovorio definitivno i dokazao svima onima koji pokušavaju danas potcjenjivati herojsku borbu naroda Jugoslavije, da oni nijesu u pravu (označila S.K.) i da to vrijeđa do dna duše naše narode. To sam podvukao zbog toga da bih dokazao da su se, na poziv druga Staljina za borbu protiv fašističkog osvajača 1941 godine, jedino narodi Jugoslavije odazvali i ne samo odazvali nego su i prije toga poziva stupili u borbu, smatrajući to svojom dužnošću, - drukčije rečeno - Komunistička partija Jugoslavije ispunila je svoj dug i povela narode Jugoslavije da se rame uz rame bore zajedno s Crvenom armijom za svoju slobodu. ${ }^{159}$

Druga, podjednako značajna promjena očitovala se u izjednačavanju NOB-a s narodnom/socijalističkom revolucijom, koji je tako od oslobodilačke borbe evoluirao u klasni rat u kojemu je pobjedu izvojevala radnička klasa, a buržoazija „pretrpjela odlučujući poraz”. ${ }^{160}$ Dok je u izlaganju na Drugom zasjedanju AVNOJ-a Tito oštro opovrgavao da je

\footnotetext{
${ }_{158}$ Podjednako, Tito podvlači da je Crvena armija ušla na jugoslavenski teritorij 1944. „uz dozvolu i pristanak NKOJ-a i Vrhovnog štaba” te nikada „nije zahtevala da joj se jugoslovenske oružane snage potčine”. J. BROZ TITO, Politički izvještaj CK KPJ, 70.-71.

159 Isto, 43.

160 Isto, 76.-77.
} 
NOB ,pokušaj komunista da uzmu vlast” ${ }^{161}$ u referatu na Petom kongresu govorio je upravo suprotno: objasnio je kako jugoslavenski komunisti nisu htjeli „stati na po puta: zbaciti kralja i ukinuti monarhiju, doći na vlast i dijeliti tu vlast s predstavnicima kapitalističke klase”, već su odlučili „poći smjelo putem potpune likvidacije kapitalizma u Jugoslaviji”. U ratu su stvoreni ključni preduvjeti koji su omogućili da „nova Jugoslavija” odmah poslije rata započne s izgradnjom socijalizma: „mi smo likvidirali stari buržoaski državni aparat” i „iskovali potpuno novu narodnu armiju, koja je (...) spremna da služi narodu i obezbjeđuje izgradnju socijalizma u našoj zemlji”. Zbog toga, zaključuje Tito, „i nije bilo potrebno poslije rata na uličnim barikadama rješavati pitanje vlasti, jer je tu vlast narod već čvrsto držao u ruci kao najveću tekovinu oslobodilačke borbe protiv okupatora i domaćih izdajnika”. ${ }^{162}$

\section{Recepcija Titova djela nakon 1948. godine}

Referatom na Petom kongresu Tito je uglavnom zaokružio svoj opus o ratu. Kasnije mu se vraćao uglavnom kroz sjećanja, intervjue i prigodne govore, a u njima je ponekad nadopunjavao, korigirao, pa i preispisivao svoje ranije radove. ${ }^{163}$ Njegov je referat sljedećih godina zadobio status kanonskog teksta prema kojemu se oblikovala, pisala i poučavala povijest NOB-a i partije: bio je ne samo glavni izvor informacija, već i interpretacija i konstrukcija značenja. Manji znanstveni i stručni radovi koji su objavljivani u okviru partijske historiografije, kao i popularni radovi objavljeni u 1950-ima, uglavnom su slijedili okvir koji je Tito postavio svojim referatom na Petom kongresu. I popunjavali ga novim pojedinostima. Pod utjecajem prikupljenih izvora Tita se ponekad i ispravljalo, ali samo u detaljima, dok se u ključni okvir i interpretacije nije zadiralo: tako je, primjerice, u prvom izdanju knjižice Historija NOP-a Čubelića i Milostića preuzeta Titova tvrdnja s Petog kongresa da je u vrijeme Šestosiječanjske diktature ubijeno i uhićeno na tisuće članova partije, da bi do sedmog izdanja ta brojka bila reducirana na stotine ubijenih i uhićenih članova partije. ${ }^{164}$

$S$ druge strane, Tita se ipak interpretiralo i reinterpretiralo na različite načine, samim time što se njegovim djelom služilo selektivno. Dobar primjer su već spomenuti popularni prikazi NOB-a i školski udžbenici. Primjerice, knjige A. Jovanovića i J. Marjanovića gotovo su u potpunosti slijedile Titov obrazac s fokusom na Vrhovni štab - štoviše, Jovanovićeva je knjižica završavala s oslobođenjem Beograda u listopadu 1944. godine. Knjižica Čubelića i Milostića isto je tako imala fokus na Vrhovni štab, ali je ipak znatno više pozornosti pridavala širenju ustanka u Hrvatskoj. U njezino posljednje, jedanaesto izdanje (1963.), unesena je i tvrdnja o sisačkom partizanskom odredu kao o prvom partizanskom odredu $u$ Jugoslaviji, što u tom trenutku nije bio sastavni dio ostalih sličnih publikacija u drugim ju-

161 J. BROZ TITO, Borba za oslobođenje Jugoslavije, 1945. ${ }^{2}$, 164. „Razvitak narodno-oslobodilačke borbe u svjetlu međunarodnih zbivanja”.

162 ISTI, Politički izvještaj CK KPJ, 82.

163 To je, primjerice, bio slučaj s „martovskim pregovorima” koji su u poratnoj Jugoslaviji bili tabu tema dok Tito o njima nije progovorio 1978. godine, prilikom proslave 35. obljetnice bitke na Neretvi, optuživši Milovana Đilasa, Koču Popovića i Vladimira Velebita da su radili protivno njegovim uputama. Vidi: Mišo LEKOVIĆ, Martovski pregovori 1943, Beograd 1985.; M. ŠUVAR, Vladimir Velebit: svjedok historije, 279.-289.; J. PIRJEVEC, Tito in tovariši, 134.

164 T. ČUBELIĆ - M. MILOSTIĆ, Pregled historije Narodnooslobodilačke borbe, 1952. ${ }^{1}$, 32.-33.; 1954. ${ }^{3}, 32.33 . ; 1957.7$, 33. 
goslavenskim republikama. ${ }^{165}$ Istovremeno je slovenski udžbenik iz tog razdoblja već tada posvetio više prostora NOB-u u Sloveniji nego u ostatku Jugoslavije (17:15 stranica), ${ }^{166}$ što je u Hrvatskoj nakratko učinjeno tek 1971. godine. ${ }^{167}$ Da je iskorak iz zadanog interpretativnog okvira bio moguć, ukazuje i niz rasprava s kraja 1950-ih i početkom 1960-ima o prikazima NOB-a, osobito ustanka. Radi se, primjerice, o raspravama o prikazu NOB-a u Vojnoj enciklopediji, ${ }^{168}$ nadalje, o polemikama Trećem kongresu jugoslavenskih historičara u Ljubljani (1961.). ${ }^{169}$ Konačno, radi se i o poznatim kontroverzama koje je izazvalo objavljivanje Pregleda istorije Saveza komunista Jugoslavije u redakciji Rodoljuba Čolakovića i knjige Velimira Terzića Jugoslavija u aprilskom ratu (1963.). ${ }^{170}$ Iako se raspravljalo i o drugim pitanjima, u središtu polemika ipak je bio prikaz ustanka, što je navelo Vladimira Bakarića da sjednici (proširene) Komisije za historiju CK SKH u ožujku 1964. izjavi kako se „dvadeset godina bavimo 1941., a za dvadeset godina možda ćemo doći i do 1942 ". ${ }^{171}$

Tako su pokušaji različitih tumačenja postali izvorištem polemika i sukoba, ne samo u historiografiji, već i u politici, a upravo su one teme koje su trebale imati primarno integracijski karakter (ne)posredno i (in)direktno ukazivale na međunacionalne tenzije i suprotnosti. Te su rasprave ukazale na još jednu bitnu promjenu: za razliku od 1940-ih i 1950-ih, kada je ključne aktere politike povijesti trebalo tražiti ponajprije (iako ne isključivo) u najužem partijskom vrhu (primjerice u tekstovima J. B. Tita, M. Đilasa, B. Ziherla i drugih), od 1960-ih su u njezinu definiranju sve značajniju ulogu imali republički akteri, republičke političke i intelektualne elite.

U 1970-ima i 1980-ima situacija se ipak mijenjala, o čemu se ovdje može donijeti tek nekoliko okvirnih naznaka. Ivan Jelić je u svojem osvrtu na historiografiju i izvore o NOB-u iz 1978. proglasio tekstove „rukovodilaca NOP-a” ponajprije „važnim izvorom”. Tako je i Titova djela ocijenio „osobito važnima i zanimljivima”, no spomenuo ih je tek na petom mjestu, iza prikaza niza zbornika građe, tiska, memoarske građe i suvremenih zapisa. ${ }^{172} \mathrm{Za}$ razdoblje nakon 1990., kada su se u javnoj sferi otvorile kritike Titova djela, odnos spram Titova narativa može se prikazati na primjeru koji je najbolje istražen: udžbenicima povijesti. ${ }^{173} \mathrm{~S}$ jedne strane, i u hrvatskim i u srpskim udžbenicima uočava se jasan odmak, a u nekim slučajevima i obračunavanje s Titovim/titovskim narativom o ratu. Hrvatski udžbenici taj su narativ uvelike napustili već u prvoj polovici 1990-ih, kada je fokus premješten na „hrvatski antifašizam” i stvaranje hrvatske države unutar stvaranja jugoslavenske

165 Tomo ČUBELIĆ - Milovan MILOSTIĆ, Pregled historije Narodnooslobodilačkog rata i revolucije naroda Jugoslavije, jedanaesto, dopunjeno izdanje, Zagreb 1963., 109.

${ }^{166}$ Ferdo GESTRIN - Jože HAINZ - Metod MIKUŽ, Zgodovina za IV: razred nižjih gimnazij, Ljubljana 1956.

167 Snježana KOREN, „Udžbenik iz 1971. i udžbenici o 1971.: udžbenički narativi i politike povijesti 1971.-2011.”, Hrvatsko proljeće: 40 godina poslije, (ur. Tvrtko Jakovina), Zagreb 2011., 309.-332.

168 Rasprave su se osobito vodile prikazu NOB-a u Hrvatskoj koji je izradio Franjo Tuđman. Vidi: Vojna enciklopedija, sv. 3 (Beograd: Izdanje redakcije Vojne enciklopedije, 1960.), 641.-650.

169 Vidi: Jugoslavenski istorijski časopis 1/1962., osobito radove Pere Morače („Društveno-politička kretanja i politika KPJ u ustanku 1941.”) i Jovana Marjanovića („Prilog izučavanju jugoslovenstva u ustanku 1941.”).

170 Pregled istorije Saveza komunista Jugoslavije, Beograd 1963.; Velimir TERZIĆ, Jugoslavija u aprilskom ratu 1941., Titograd 1963.). Također: Putovi revolucije, II (1964.), 3.-4.; Franjo TUĐMAN, Usudbene povjestice, Zagreb 1995.; Zdenko RADELIĆ, „Institut za historiju radničkog pokreta/Institut za historiju radničkog pokreta Hrvatske 1961. - 1990.", Pola stoljeća prošlosti: Hrvatski institut za povijest (1961. - 2011.), Zagreb 2011.; Dino MUJADŽEVIĆ, Bakarić: politička biografija, Zagreb 2011.

171 Jugoslavija u Hrvatskoj, (prir. Goran Babić), Beograd 2000., 130.

172 Ivan JELIĆ, Hrvatska u ratu i revoluciji 1941-1945, Zagreb 1978., 258.

173 Bibliografija o tome je iznimno opsežna, a najkoncizniji pregled materije, istraživanja i literature mogu se naći u knjizi "Transistion" and the Politics of History Education in Southeast Europe, (ur. Augusta Dimou), Göttingen 2009. 
federacije, dok je to u srpskim udžbenicima učinjeno nešto kasnije, kada je četnički pokret izjednačen $s$ NOP-om. ${ }^{174} \mathrm{~S}$ druge strane, njegovi se tragovi mogu zapaziti sve do danas, $u$ opisima, izrazima i ocjenama koje autori svjesno ili nesvjesno ugrađuju u svoje tekstove. Primjera ima mnogo, a možda je najupečatljiviji srpski udžbenik iz 2005., gdje je pripovijedanje o ratu i dalje organizirano po neprijateljskim ofenzivama, ali su se umjesto brojčanih odrednica koristila njemačka kodna imena (operacija Weiss, operacija Schwarz itd.)! $!^{175} \mathrm{Za}$ precizniji odgovor na pitanje o tragovima koje je Titov prikaz rata ostavio na suvremenu historiografiju i popularne prikaze potrebna su ipak daljnja istraživanja ${ }^{176}$ - njih opus Josipa Broza Tita svakako zaslužuje zbog nasljeđa koje je ostavio na pojmovnoj, faktografskoj, interpretativnoj, pa i na emocionalnoj razini.

\section{$\cos$}

\section{World War II in Josip Broz Tito's SPEECHES AND WRITING (I940-I948)}

The story of the People's Liberation Struggle constituted an important reference point in the Yugoslav communist government's legitimization discourse. To a large extent, it drew from the works of Josip Broz Tito, who wrote his most important contributions to the topic between 1941 and 1948, revisiting the subject of the war in his memoirs, interviews and commemorative speeches. This paper provides a context and an analysis of his articles, political reports and commemorative speeches written in wartime years and published official publications like the Proleter and the Borba, as well as those published by the Supreme Military Headquarters and AVNOJ (such as the Bilten Vrhovnog štaba or Nova Jugoslavija), the daily press etc. The paper analyzes key patterns and perceptions of the war as depicted in Tito's works, for instance, the image of the first Yugoslav state, the "uprising of Yugoslav peoples", the construct of the "seven enemy offensives", the creation of a "People's Army" and a "people's government", the attitude towards the monarchy, federation, the national question, as well as the attitude towards the allies (the USSR, the US and the UK) and the enemies (the Chetniks, the Ustashe and the exiled government). Particular attention is devoted to the report Tito gave at the Fifth Congress of the Communist Party of Yugoslavia in 1948, as it represented an overview of the history of the Communist Party of Yugoslavia from Tito's perspective. An attempt is also made to determine the differences between the report and earlier texts, pinpointing new meanings attributed to the People's Liberation Struggle in the political context which emerged following the clash with the USSR. The final chapter deals with the reception of Tito's works after 1948.

Keywords: Josip Broz Tito, World War II, the People's Struggle, wartime speeches and articles, report at the Fifth Congress of the Communist Party of Yugoslavia, story, uprising, the Seven Offensives, revolution, memories of war

\section{$\cos$}

$\overline{174}$ Suzana RAJIĆ - Kosta NIKOLIĆ - Nebojša JOVANOVIĆ, Istorija za 8. razred osnovne škole, Beograd $2005 ., 139$.

175 Isto, 141.-150.

176 Neke je uvide u svojim radovima ponudio Todor KULJIĆ. Vidi: ISTI, Sećanje na Titoizam: između diktata i otpora, Beograd 2011. i ISTI, Tito: sociološkoistorijska studija, Zrenjanin 2012. 


\section{Bibliografija}

\section{Arhivska grada}

Hrvatski državni arhiv (HR HDA), fond Centralnog komiteta SKH, 1220 CK SKH.

\section{Časopisi}

Bilten Glavnog/Vrhovnog štaba

Jugoslavenski istorijski časopis

Komunist

Putovi revolucije

\section{Literatura i objavljeni izvori}

Dušan BILANDŽIĆ, Hrvatska moderna povijest, Zagreb 1999.

Ljubo BOBAN, Kontroverze iz povijesti Jugoslavije 2, Zagreb 1989.

Josip BROZ TITO, Autobiografska kazivanja, tom I. i II, Beograd 1982.-1983.

Josip BROZ TITO, Borba za oslobođenje Jugoslavije: članci i govori iz narodno-oslobodilačke borbe 1941-1944., Beograd 1944.

Josip BROZ TITO, Borba za oslobodenje Jugoslavije: članci i govori iz narodno-oslobodilačke borbe 1941-1944., drugo, dopunjeno izdanje, Beograd 1945.

Josip BROZ TITO, Borba za oslobodenje Jugoslavije: 1941-1945, sv. 1, Zagreb 1947.

Josip BROZ TITO, Izbor iz djela. Knj. 2: Radnička klasa i Savez komunista Jugoslavije 1926-1977, (ur. Muhamed Filipović), Sarajevo 1979.

Josip BROZ TITO, Izbor iz djela. Knj. 3: Nacionalno pitanje i revolucija, (ur. Muhamed Filipović), Sarajevo 1979.

Josip BROZ TITO, Opštenarodna odbrana i društvena samozaštita, Sarajevo 1980.

Josip BROZ TITO, Politički izvještaj Centralnog komiteta Komunističke partije Jugoslavije: referat održan na Vkongresu KPJ, Beograd 1948.

Josip BROZ TITO, „U čemu je specifičnost oslobodilačke borbe i revolucionarnog preobražaja nove Jugoslavije”, Komunist 1/1946., 1.-9.

Fikreta BUTIĆ-JELIĆ, Hrvatska seljačka stranka, Zagreb 1983.

Tomo ČUBELIĆ - Milovan MILOSTIĆ, Pregled historije Narodnooslobodilačke borbe Jugoslavije, Zagreb 1952.

Tomo ČUBELIĆ - Milovan MILOSTIĆ, Pregled historije Narodnooslobodilačkog rata i revolucije naroda Jugoslavije, jedanaesto, dopunjeno izdanje, Zagreb 1963.

Vladimir DEDIJER, Četvrta i Peta Hitlerova ofenziva na partizane Jugoslavije, Kraj Drežnice u šumi Javornici u Gorskom Kotaru 1943.

Vladimir DEDIJER, Josip Broz Tito: prilozi za biografiju, Zagreb 1952.

Vladimir DEDIJER, Novi prilozi za biografiju Josipa Broza Tita, Rijeka 1981.

Dix années d'historiographie yougoslave 1945-1955, (ur. Jorjo Tadić), Beograd 1955.

Drugo zasjedanje Antifašističkog vijeća narodnog oslobodenja Jugoslavije, Zagreb 1945.

Ferdo GESTRIN - Jože HAINZ - Metod MIKUŽ, Zgodovina za IV: razred nižjih gimnazij, Ljubljana 1956. 
Ivan JELIĆ, Hrvatska u ratu i revoluciji 1941 - 1945, Zagreb 1978.

Ivan JELIĆ, Komunistička partija Hrvatske 1937 - 1945, knj. I i II, Zagreb 1981.

Ivan JELIĆ, Tragedija u Kerestincu. Zagrebačko ljeto 1941., Zagreb 1986.

Arso JOVANOVIĆ, Šesta i sedma neprijateljska ofanziva, Beograd 1944.

Arso JOVANOVIĆ, Pregled narodnooslobodilačke borbe, Beograd 1946.

Jugoslavija u Hrvatskoj, (prir. Goran Babić), Beograd 2000.

Snježana KOREN, Politika povijesti u Jugoslaviji (1945-1960): Komunistička partija Jugoslavije, nastava povijesti, historiografija, Zagreb 2012.

Snježana KOREN, „Udžbenik iz 1971. i udžbenici o 1971.: udžbenički narativi i politike povijesti 1971.-2011.”, Hrvatsko proljeće: 40 godina poslije, (ur. Tvrtko Jakovina), Zagreb 2011., 309.-332.

Todor KULJIĆ, Sećanje na Titoizam: izmedu diktata i otpora, Beograd 2011.

Todor KULJIĆ, Tito: sociološkoistorijska studija, Zrenjanin 2012.

Mišo LEKOVIĆ, Martovski pregovori 1943, Beograd 1985.

Magdalena NAJBAR-AGIČIĆ, U skladu s marksizmom ili činjenicama? Hrvatska historiografija 1945-1960., Zagreb 2013.

Jovan MARJANOVIĆ, Narodnooslobodilački rat, naroda revolucija u Jugoslaviji 1941-1945: kratak pregled, Beograd 1957.

Stjepan MATKOVIĆ „Ocjene Uprave za agitaciju i propagandu KP Hrvatske o povjesničarima na Sveučilištu u Zagrebu do početka 1950-ih”, Kultura sjećanja: 1945. Povijesni lomovi i svladavanje prošlosti, (ur. Sulejman Bosto i Tihomir Cipek), Zagreb 2009.

Metoda MIKUŽ, Pregled razvoja NOB u Sloveniji, Beograd 1956.

Olivera MILOSAVLJEVIĆ, „Titov Jugoslaven - nacionalni ili državni identitet?”, Dijalog povjesničara-istoričara, knj. 7, Zagreb 2003.

Dino MUJADŽEVIĆ, Bakarić: politička biografija, Zagreb 2011.

Osmi kongres Saveza komunista Jugoslavije, Beograd 1964.

Peta zemaljska konferencija KPJ (19-23. oktobar 1940), (priredili Pero Damjanović, Milovan Bosnić i Dragica Lazarević), Beograd 1980.

Peti kongres Komunističke partije Jugoslavije 21. - 28. jula 1948. Stenografske bilješke, S. 1., 1949.

Peti kongres Saveza komunista Hrvatske. Zagreb, 26 - 29. travnja 1965. Stenografske bilješke, Zagreb 1966.

Branko PETRANOVIĆ, Istorija Jugoslavije 1918 - 1988, Beograd 1988.

Branko PETRANOVIĆ - Momčilo ZEČEVIĆ, Jugoslavija 1918 - 1984. Zbirka dokumenata, Beograd 1985.

Jože PIRJEVEC, Tito in tovariši, Ljubljana 2011.

Povijest Saveza komunista Jugoslavije, Beograd 1985.

Pregled istorije Saveza komunista Jugoslavije, Beograd 1963.

Zdenko RADELIĆ, „Institut za historiju radničkog pokreta/Institut za historiju radničkog pokreta Hrvatske 1961. - 1990.”, Pola stoljeća prošlosti: Hrvatski institut za povijest (1961. - 2011.), Zagreb 2011.

Suzana RAJIĆ - Kosta NIKOLIĆ - Nebojša JOVANOVIĆ, Istorija za 8. razred osnovne škole, Beograd,2005.

Đorđe STANKOVIĆ - Ljubodrag DIMIĆ, Istoriografija pod nadzorom. Prilozi istoriji istoriografije, Beograd 1996. 
„Šesti plenum Centralnog komiteta Saveza komunista Jugoslavije, 13-14 mart 1956”, Komunist, 3-4/1956., 149.-263.

Mira ŠUVAR, Vladimir Velebit: svjedok historije, Zagreb 2001.

Velimir TERZIĆ, Jugoslavija u aprilskom ratu 1941., Titograd 1963.

Jozo TOMASEVICH, Četnici u Drugom svjetskom ratu 1941 - 1945., Zagreb 1979.

Jozo TOMASEVICH, Rat i revolucija u Jugoslaiji 1941-1945. Okupacija i kolaboracija, Zagreb 2010.

"Transistion" and the Politics of History Education in Southeast Europe, (ur. Augusta Dimou), Göttingen 2009.

Franjo TUĐMAN, Usudbene povjestice, Zagreb 1995.

Zbornik dokumenata i podataka o narodnooslobodilačkom ratu jugoslovenskih naroda. Tom II: Bilten Vrhovnog štaba Narodnooslobodilačke vojske Jugoslavije 1941-1945, Beograd 1949. 